\title{
$\angle S$ Research Suare \\ Potentially Toxic Elemental Contamination in Wainivesi River, Fiji Impacted by Gold-mining Activities using Chemometric Tools and SOM Analysis
}

\section{Satendra Kumar}

The University of the South Pacific

Abu Reza Md. Towfiqul Islam ( $\square$ towfiq_dm@brur.ac.bd)

Begum Rokeya University https://orcid.org/0000-0001-5779-1382

Md. Hasanuzzaman

Begum Rokeya University

Roquia Salam

Begum Rokeya University

Md. Saiful Islam

Patuakhali Science and Technology University

Rahat Khan

Bangladesh Atomic Energy Commission

M. Safiur Rahman

Bangladesh Atomic Energy Commission

Subodh Chandra Pal

The University of Burdwan

Mir Mohammad Ali

Sher-e-Bangla Agricultural University

Abubakr M. Idris

King Khalid University

Williamson Gustave

University of the Bahamas

Ahmed Elbeltagi

Mansoura University

\section{Research Article}

Keywords: Surface water quality, sediment quality, self-organizing map, Environmental risk, Entropy theory.

Posted Date: November 1st, 2021

DOI: https://doi.org/10.21203/rs.3.rs-941620/v1 
License: (9) (i) This work is licensed under a Creative Commons Attribution 4.0 International License. Read Full License

Version of Record: A version of this preprint was published at Environmental Science and Pollution Research on January 28th, 2022. See the published version at https://doi.org/10.1007/s11356-022-18734-w. 


\section{Abstract}

Potentially toxic elements (PTEs) contamination in Wainivesi River, Fiji triggered by gold-mining activities is a major public health concern deserving attention. However, chemometric approaches and pattern recognition of PTEs in surface water and sediment are yet hardly studied in Pacific Island countries like Fijin urban River. In our study, twenty-four sediment and eight water sampling sites from the Wainivesi River, Fiji were explored to evaluate the spatial pattern, eco-environmental pollution, and source apportionment of PTEs. This analysis was done using an integrated approach of self-organizing map (SOM), principle component analysis (PCA), hierarchical cluster analysis ( $\mathrm{HCA})$, and indexical approaches. The PTEs average concentration is decreasing order of $\mathrm{Fe}>\mathrm{Pb}>\mathrm{Zn}>\mathrm{Ni}>\mathrm{Cr}>\mathrm{Cu}>\mathrm{Mn}>\mathrm{Co}>\mathrm{Cd}$ for water and $\mathrm{Fe}>\mathrm{Zn}>\mathrm{Pb}>\mathrm{Mn}>\mathrm{Cr}>\mathrm{Ni}>\mathrm{Cu}>\mathrm{Co}>\mathrm{Cd}$ for sediment, respectively. Outcomes of eco-environmental indices including contamination and enrichment factors, and geo-accumulation index differed spatially indicated that majority of the sediment sites were highly polluted by $\mathrm{Zn}, \mathrm{Cd}$, and $\mathrm{Ni}$. $\mathrm{Cd}$ and $\mathrm{Ni}$ contents can cause both ecological and human health risks. According to PCA, two sources such as point and geogenic sources for sediment and also two sources including weathering of rock-water and anthropogenic sources of PTEs for water were identified in the study area. The SOM analysis identified three spatial patterns e.g., Cr-Co-Zn-Mn, Fe-Cd and Ni-Pb-Cu in water and Zn$\mathrm{Cd}-\mathrm{Cu}-\mathrm{Mn}, \mathrm{Cr}-\mathrm{Ni}$ and $\mathrm{Fe}, \mathrm{Co}-\mathrm{Pb}$ in sediment. Spatial distribution of entropy water quality index values depicted that northern and northwestern areas possess 'poor' to 'extremely-poor' quality water. The entropy weights indicated $\mathrm{Zn}, \mathrm{Cd}$ and $\mathrm{Cu}$ as the major pollutants in deteriorating the water quality. Our finding provides a baseline database with eco-environmental and health risk measures for the Wainivesi river contamination.

\section{Introduction}

In recent years, potentially toxic elements (PTEs) contamination in water and sediments of the aquatic system has attracted global attention owing to their persistence and non-biodegradable nature. Moreover, these PTEs are known to be toxic and poses a major risk to human and ecological health (Ali et al. 2016, 2018; Islam et al. 2018; 2020a; 2021; Pandey et al. 2019; Ustaoğlu and Islam, 2020; Kumar et al., 2021). Considerable quantities of hazardous chemicals especially PTEs such as chromium (Cr), nickel (Ni), cobalt (Co), cupper (Cu), mercury $(\mathrm{Hg})$, arsenic $(\mathrm{As})$, cadmium $(\mathrm{Cd})$, and lead $(\mathrm{Pb})$ have been discharged into the rivers system due to the rapid expansion of emissions sources, global population growth, improper wastewater disposal and agricultural runoff (Türkmen et al., 2011; Srebotnjak et al. 2012, Su et al. 2013, Islam et al. 2014; Kabir et al., 2021). Therefore, the fate of PTEs in the aquatic ecosystems is of particular importance as PTEs bind with suspended particulate or organic matter and ultimately end up bound with the riverine sediments (Varol and Sen, 2012). However, the spread of PTEs to the aquatic bodies especially surface sediments occur naturally and anthropogenically via chemical weathering motor vehicles exhaust gases, mining activities, toxic elements containing fertilizers and pesticides, various urban and industrial activities (Tokatlı et al., 2015; Islam et al., 2017; Khan et al., 2020). Furthermore, continuous accumulation of PTEs in the aquatic system severely degrades the environmental quality and unfavorably affects the biosphere structure, triggering changes in the biogeochemical cycles (Alizadeh et al., 2018; Maria Cavadas Morais Couto et al., 2019). The behavior of PTEs in the riverine freshwater is a function of the substrate and suspended sediment composition and the water chemistry (Mohiuddin et al., 2012). During transport, PTEs may undergo various changes in their speciation due to changes in sediment and water chemistry, reductive dissolution, precipitation, sorption, and 
complication process (Mohiuddin et al., 2011, 2012; Islam et al., 2015). These changes are not only effect the fate and transport of the PTEs, but also their toxicity. Therefore, the distribution, possible ecological risks and sources identification of PTEs in the riverine water and sediment is critical for efficient environmental risk perspective (Tepe et al., 2017; Kormoker et al., 2019a).

Investigation of PTEs in the surface sediments could be utilized to evaluate the anthropogenic effects and risks posed by improper waste discharge to the riverine ecosystems (Islam et al, 2020a; Liu et al., 2018). Standard reference dataset on PTEs in aquatic media are very scarce in Fiji and are considered as a restricted access in generating the association between PTEs accumulation and their source distribution (Kumar et al., 2021). To best of our knowledge, thus far, limited attentions have been paid to PTEs evaluation in surficial water and sediments of Wainivesi River adjacent to Wainivesi gold mining areas. Hence, accurate source distribution and ecological risk evaluation of PTEs in riverine sediments are urgently needed. Some sediment quality indices have been recognized and extensively applied by many researchers in order to evaluate PTEs pollution and ecological risks in sediments from riverine aquatic environments (Ali et al., 2018; Hu et al., 2018; Islam et al., 2020b; Xiao et al., 2019). These indices are mainly classified into three categories, such as contaminants identification, background enrichment and ecological risk (Kumar et al., 2020; Rinklebe et al., 2019; Song et al., 2017). Several methods have been used to determine the pollution level in sediments, the probable ecological risk index (RI) and the pollution load index (PLI) to assess the toxic effects of PTEs on sediments (Islam et al., 2018; Kormoker et al., 2019b; Khan et al., 2020). Therefore, this research has focused on the indexical and chemometric tools to evaluate the pollution levels of PTEs and source apportionment.

In recent decades, Tailevu Province, Central Division, Fiji has experienced fast urbanization due to its rapid industrial and gold mining growth. Consequently, today the rapid unplanned urbanization and industrialization with the anthropogenic inputs of PTEs in this town is a matter of concern. The Wainivesi River basin is the most popular river system that crosses through the north of Navunisole town, posing a socio-economic benefit to its nearby riverine dwellers (Maata and Singh, 2008). In Fiji, gold mining activities have been evolved in the fourth century, and since that time, gold has been mined using the mercury amalgamation approach from alluvial sedimentary rock of Wainivesi River waterways and subsurface sediments along the side of dried-up valleys (Diarra and Prasad, 2020). The economy of Fiji depends on gold mining development and gold is the country's most export product (Mines, 2019; Diarra and Prasad, 2020). In Fiji, most of the gold formed by goldamalgamation procedure derived from goldfields distributed in the Central Division of the country (Maata and Singh, 2008), which is drained by the Wainivesi River system. About 7549 ha of landmasses have five tailings dams where all sludge waste particles from Votukoula gold mining area are deposited (Kumar et al. 2021). In this river system, PTEs comes primarily from mineral ores processing and the disposal of tailing and wastewater across gold mines. This result in numerous detrimental effects on the geochemistry and ecosystem of the receiving water bodies (Grimalt et al., 1999; Mora et al., 2019). Thus, assessment of PTEs accumulation in the Wainivesi River sediment is a topic of concern for sustainable PTEs management in Fiji.

At the solid gold tailings some sulfides mineralization occurs to produce acids that could trigger leaching of PTEs from gold tailing dams and thus makes a probable risk to the surrounding environment (Hadzi et al., 2018; Adewumi and Laniyan, 2020). The gold-mining industries favors PTEs mobility in the water bodies of Wainivesi River, Fiji and are the major cause for PTEs pollution of this riverine ecosystem (Mora et al., 2019). Recently, gold mining activities in Fiji has observed a pipeline failure around gold tailing dams around the 
Nasivi River which has since been demarcated as a key disaster event. Gold-mining that includes on-site ore processing that produces large quantities of tailings can have major impacts off-site on groundwater, riverine streams, wildlife and the inhabitants (Zabowski et al., 2001). A few studies have stated that inhabitants near the gold-mining area have raised their disquiet on the elevated level of contamination of PTEs in surface water, and drinking water (Ackley, 2008; Matakarawa, 2018, Kumar et al. 2021).

Numerous studies in the goldmine regions on the contamination and risks of PTEs via different environmental media have been well documented around the globe, e.g., in China (Huang et al., 2020), Brazil (Pereira et al., 2020), Nigeria (Adewumi and Laniyan, 2020), Ghana (Hadzi et al., 2018), Bolivia (Pavilonis et al., 2017), Papua New Guinea (Kapia et al., 2016). However, only limited information is available on PTEs contamination from the gold mining activities around the Wainivesi River in Fiji so far (Matakarawa, 2018; Kumar et al., 2021). Therefore, this is the first study to appraise the contamination levels of PTEs in water and sediments of Wainivesi River, Tailevu Province, Fiji.

In the present research, we hypothesized that inhabitants of the Tailevu Province, Central Division, Fiji are concerned about the high levels of PTEs through aquatic media, and the local people are suffering from freshwater shortage, and most of people rely on the river water for domestic, industrial and animal feeding purposes. Due to the PTEs potential risk in water and sediment of Wainivesi River through the improper disposal of effluents from gold-mining, this riverine water, sediment and ecosystem may be polluted. Due to the surrounding area of the gold-mine to one of the major rivers in Fiji (Wainivesi River), the possible movement of mine-induced PTEs to this river is of paramount concern. Thus, there is a crucial requirement to concurrently monitor the level of PTEs contents and related eco-environmental risks through aquatic media from the gold-mining activities, to safeguard against the diffusion of diseases and fatalities. The main goals of this study are to estimate the pollution level of PTEs in river water and surficial sediments; to appraise the water quality and possible source patterns of the PTEs in the water bodies, and to evaluate the ecological risk and possible source of PTEs in sediments. The novelty of this research is that it is the preliminary inclusive study on riverine water and sediments resource pollution affected by gold-mining area of central Fiji.

\section{Materials And Method}

\subsection{Study Area description}

This work was performed at Wainivesi River which passes via Wainivesi Mine that is situated $10.14 \mathrm{~km}$ northwest of Korovou town, in the inland of Tailevu. The GIS sites for the various sampling locations are displayed in supplementary Table S1 and the sampling sites are outlined in Fig. 1. The location of the Wainivesi mine close to the Wainivesi River makes it an important region to assess the PTEs. Korovou town is one of 25 cities in Fiji and ranks 23 in the Fijian population. In the Wainivesi area most people are heavily dependent on farming. Major type of farming is vegetables and root crops. Also most farmers are commercial dairy farmers. Most of the cattle's drink water from Wainivesi River. The climate is mostly tropical rainforest, experienced by a distinctive rainy period from six months (November-April) and a dry period is noticed from other six months (May-October). The annual mean precipitation ranged from 2100 to $4200 \mathrm{~mm}$ during the rainy period. The Wainivesi River runs from the hills that flow downstream sides which passes Korovou town. When heavy precipitation happens in the Korovou town, a waterway of the Wainivesi River gets huge 
household domestic waste material, which noticeably attributed to flood that accumulated with mud and other debris particles. The Tailevu Province, Fiji is witnessing a precise gold occurrence in the history of the resources industry.

\subsection{Sample collections and procedures}

Benthic surficial sediment and water samples were collected from 8 diverse sample sites of Wainivesi River, Tailevu, Fiji considering the presence of mining outlets (Fig. 1, Table S1). Sample sites were $\sim 500-1000 \mathrm{~m}$ apart from each other and the sample processes encompass $\sim 4.8 \mathrm{~km}$ of Wainivesi River. From each sampling sites, vertical sediment columns $(15 \mathrm{~cm}$ ) were collected by using a Polyvinyl chloride (PVC) pipe corer (Tamim et al., 2016). Sediment columns were then divided into three portions in terms of their vertical depth (0-5cm, 5$10 \mathrm{~cm}, 10-15 \mathrm{~cm}$ ) followed by preserving in zip-lock bags with proper labeling. Sediment samples were oven dried $\left(60^{\circ} \mathrm{C}\right)$, were sieved through $2 \mathrm{~mm}$ nylon sieve to remove the botanical-debris, lumps and stones. To obtain homogenized powder form, samples were then pulverized using a ring mill. However, representative surface water sampling collection procedures from each sample sites were identical as those of prior studies (Siddique et al., 2021; Islam et al., 2020a). Concisely, two sets of combined water samples from each sample sites were obtained in which a single set of sample was preserved as it was while the another set were filtered and acidified (con. $\mathrm{HNO}_{3} ; \mathrm{pH}<2$ ) for subsequent laboratory analysis.

\subsection{Analytical processes}

Nitric Acid-Perchloric Acid-Hydrofluoric Acid $\left(\mathrm{HNO}_{3}-\mathrm{HClO}_{4}-\mathrm{HF}\right)$ based digestion procedure for the sediment samples was identical as those mentioned in Khan et al. (2015a, b). Briefly, 100mg of sediment samples were thermally decomposed by sequential acid treatments. Elemental concentrations in the sediment samples were measured by atomic absorption spectrophotometer (AAS) (Perkin Elmer: AAnalyst 400, USA). Data quality assuring protocols including instrumental calibration, procedure blank monitoring, using double deionized water for dilution and replicate measurements of relevant reference materials were same as those in Ahsan et al. (2019). For river-water samples, physical and chemical parameters including temperature, $\mathrm{pH}$, oxygen reduction potential (ORP), electrical conductivity (EC), total dissolved solids (TDS), and dissolved oxygen (DO) were measured in the un-acidified samples by portable Horiba-52 Multi-meter (Japan) at the sample locations. On the other hand, AAS-based elemental analysis was executed by using the acidified water samples. Analytical processes and quality ensuring processes were essentially same as those of our previous studies (Ahmed et al., 2021; Hasan et al., 2021; Kumar et al., 2021). For quality control purpose, PTEs abundances from replicate estimations $(n=3)$ of standard materials NIST-SRM-8704 (sediment) and NISTSRM-1640 (normal water) along with their limits of detection (LOD: $3 \sigma$ ) and limits of quantification (LOQ: 10б) are outlined in Table S2.

\subsection{Water quality and eco-environmental indices assessment}

An integration of particular and various indices was employed for assessment of PTEs contamination level (Table 1). Eco-environmental indices such as $I_{\text {geo }}$ (Muller, 1979), EF (Kumar et al., 2021) and CF (Hakanson, 1980), were used for the evaluation of PTEs contamination. On the other hand, PLI (Tomlinson et al., 1980), $C_{d}$ (Hakanson, 1980), modified degree of contamination ( $\mathrm{mC}_{\mathrm{d}}$ ) (Abrahim, and Parker, 2008), and RI (Khan et al., 2020) were chosen for the integrated evaluation of pollution in sediment. Moreover, chemometric tool such as the entropy water quality index developed by Shannon, (1948) was utilized for surface water in this study. In 
the current work, indexical approaches such as $\mathrm{I}_{\text {geo }}, \mathrm{EF}, \mathrm{CF}, \mathrm{C}_{\mathrm{d}}, \mathrm{mC}_{\mathrm{d}}, \mathrm{PLI}$, and $\mathrm{RI}$ were adopted for appraising the sediment's contamination and possible ecological risks while entropy water quality index (EWQI) were employed for assessing the water quality status in the Wainivesi River. Khan et al. (2020) applied element abundances of UCC as the standard dataset for computed these indices while Rubio et al. (2000) recommended the application of regional base line datasets. Furthermore, the method of establishing limit datasets is to compare the major PTEs contents in polluted and non-polluted sediments that are analogous in terms of mineralogical and textural perspective (e.g., Hornung et al., 1989). However, the regional changes of sampling collection sites between the polluted and non-polluted sediments may trigger the considerable variations in element compositions. Therefore, to have the optimal baseline data, deep sedimentary layer can be used (Siegel et al., 1994) to measure those aforementioned indices. According to our study, deep sediment datasets from sample site $(6 \mathrm{C})$ were employed for calculating these indices for sediments. The calculation results of $I_{\text {geo, }}$ and CF will assist and help to provide a robust evaluation. Conversely, EWQI was applied in the information entropy theory, in which the entropy was regarded for taking into consideration as information. The adaption this entropy theory to identify the weight of each parameter can lessen omission causing by ignoring the relative arbitrary weight (Pei-Yue et al., 2010; Islam et al. 2017). In our work, the EWQI is employed to show the current status of the river water quality due to its recognition, strength, and reliability (Islam et al., 2020b). All the calculated formulas, brief explanation and importance of these eco-environmental indices are outlined in Table 1 
Table 1

Mathematical expressions and physical significances of environmental and ecological indices.

\begin{tabular}{|c|c|c|c|c|}
\hline Indices & Mathematical expressions & Classification & $\begin{array}{l}\text { Contamination } \\
\text { degree }\end{array}$ & References \\
\hline \multirow{7}{*}{$\begin{array}{l}\text { Geo- } \\
\text { accumulation } \\
\text { index, I } \text { Ieo }_{\text {geo }}\end{array}$} & \multirow{7}{*}{$\begin{array}{l}I_{\text {geo }}=\log _{2}\left(\frac{C_{n}}{1.5 \times B_{n}}\right) \text { Where, } \mathrm{C}_{\mathrm{n}} \\
\text { is the measured elemental } \\
\text { concentration in sediment and } \mathrm{B}_{\mathrm{n}} \text { is } \\
\text { the background heavy metal } \\
\text { concentrations }\end{array}$} & $\mathrm{I}_{\mathrm{geo}}<0$ & $\begin{array}{l}\text { Practically } \\
\text { uncontaminated }\end{array}$ & \multirow[t]{7}{*}{$\begin{array}{l}\text { Müller, } \\
(1979)\end{array}$} \\
\hline & & $0 \leq \mathrm{I}_{\mathrm{geo}}<1$ & $\begin{array}{l}\text { Uncontaminated } \\
\text { to moderately } \\
\text { contaminated }\end{array}$ & \\
\hline & & $1 \leq \mathrm{I}_{\mathrm{geo}}<2$ & $\begin{array}{l}\text { Moderately } \\
\text { contaminated }\end{array}$ & \\
\hline & & $2 \leq \mathrm{I}_{\mathrm{geo}}<3$ & $\begin{array}{l}\text { Moderately to } \\
\text { heavily } \\
\text { contaminated }\end{array}$ & \\
\hline & & $3 \leq \mathrm{I}_{\mathrm{geo}}<4$ & $\begin{array}{l}\text { Heavily } \\
\text { contaminated }\end{array}$ & \\
\hline & & $4 \leq \mathrm{I}_{\mathrm{geo}}<5$ & $\begin{array}{l}\text { Heavily to } \\
\text { extremely } \\
\text { contaminated }\end{array}$ & \\
\hline & & $\mathrm{I}_{\mathrm{geo}} \geq 5$ & $\begin{array}{l}\text { Extremely } \\
\text { contaminated }\end{array}$ & \\
\hline \multirow[t]{4}{*}{$\begin{array}{l}\text { Contamination } \\
\text { factor, CF }\end{array}$} & \multirow{4}{*}{$\begin{array}{l}C F=\frac{C_{n}}{B_{n}} \text { Where, } \mathrm{C}_{\mathrm{n}} \text { and } \mathrm{B}_{\mathrm{n}} \text { are the } \\
\text { measured and background } \\
\text { elemental concentrations in } \\
\text { sediment \& water, respectively. }\end{array}$} & $\mathrm{CF}<1$ & $\begin{array}{l}\text { Low } \\
\text { contamination }\end{array}$ & \multirow[t]{4}{*}{$\begin{array}{l}\text { Hakanson, } \\
(1980)\end{array}$} \\
\hline & & $1 \leq \mathrm{CF}<3$ & $\begin{array}{l}\text { Moderate } \\
\text { contamination }\end{array}$ & \\
\hline & & $3 \leq \mathrm{CF}<6$ & $\begin{array}{l}\text { Considerable } \\
\text { contamination }\end{array}$ & \\
\hline & & $C F \geq 6$ & $\begin{array}{l}\text { Very high } \\
\text { contamination }\end{array}$ & \\
\hline \multirow{6}{*}{$\begin{array}{l}\text { Modified } \\
\text { degree of } \\
\text { contamination, } \\
\mathrm{mC}_{\mathrm{d}}\end{array}$} & \multirow{6}{*}{$\begin{array}{l}m C_{d}=\frac{1}{n} \sum_{i=1}^{n} C F_{i} \text { where, } \mathrm{CF} \text { is the } \\
\text { contamination factor }\end{array}$} & $\mathrm{mC}_{\mathrm{d}}<1.5$ & Uncontaminated & \multirow{6}{*}{$\begin{array}{l}\text { Abrahim, } \\
\text { and Parker, } \\
\text { (2008) }\end{array}$} \\
\hline & & $1.5 \leq \mathrm{mC}_{\mathrm{d}}<2$ & $\begin{array}{l}\text { Slightly } \\
\text { contaminated }\end{array}$ & \\
\hline & & $2 \leq \mathrm{mC}_{\mathrm{d}}<4$ & $\begin{array}{l}\text { Moderately } \\
\text { contaminated }\end{array}$ & \\
\hline & & $4 \leq \mathrm{mC}_{\mathrm{d}}<8$ & $\begin{array}{l}\text { Moderately to } \\
\text { heavily } \\
\text { contaminated }\end{array}$ & \\
\hline & & $8 \leq \mathrm{mC}_{\mathrm{d}}<16$ & $\begin{array}{l}\text { Heavily } \\
\text { contaminated }\end{array}$ & \\
\hline & & $16 \leq \mathrm{mC}_{\mathrm{d}}<32$ & $\begin{array}{l}\text { Severely } \\
\text { contaminated }\end{array}$ & \\
\hline
\end{tabular}




\begin{tabular}{|c|c|c|c|c|}
\hline Indices & Mathematical expressions & Classification & $\begin{array}{l}\text { Contamination } \\
\text { degree }\end{array}$ & References \\
\hline & & $\mathrm{mC}_{\mathrm{d}}>32$ & $\begin{array}{l}\text { Extremely } \\
\text { contaminated }\end{array}$ & \\
\hline \multirow{4}{*}{$\begin{array}{l}\text { Degree of } \\
\text { contamination, } \\
\mathrm{C}_{\mathrm{d}}\end{array}$} & \multirow{4}{*}{$\begin{array}{l}C_{d}=\sum_{i=1}^{n} C F_{i} \text { where, } \mathrm{CF} \text { is the } \\
\text { contamination factor }\end{array}$} & $\mathrm{C}_{\mathrm{d}}<8$ & $\begin{array}{l}\text { Low degree of } \\
\text { contamination }\end{array}$ & \multirow[t]{4}{*}{$\begin{array}{l}\text { Hakanson, } \\
(1980)\end{array}$} \\
\hline & & $8 \leq C_{d}<16$ & $\begin{array}{l}\text { Moderate } \\
\text { degree of } \\
\text { contamination }\end{array}$ & \\
\hline & & $16 \leq \mathrm{C}_{\mathrm{d}}<32$ & $\begin{array}{l}\text { Considerable } \\
\text { degree of } \\
\text { contamination }\end{array}$ & \\
\hline & & $C_{d}>32$ & $\begin{array}{l}\text { High degree of } \\
\text { contamination }\end{array}$ & \\
\hline \multirow[t]{7}{*}{$\begin{array}{l}\text { Enrichment } \\
\text { factor, EF }\end{array}$} & \multirow{7}{*}{$\begin{array}{l}E F=\frac{\left(C_{n} / F e\right) \text { Sample }}{\left(B_{n} / F e\right) \text { Background }} \text { Where, } \mathrm{C}_{\mathrm{n}} \\
\text { is the measured elemental } \\
\text { concentration in sediment and } \mathrm{B}_{\mathrm{n}} \text { is } \\
\text { the background heavy metal } \\
\text { concentrations }\end{array}$} & $\mathrm{EF}<1$ & $\begin{array}{l}\text { Elemental } \\
\text { mobilization }\end{array}$ & \multirow[t]{7}{*}{$\begin{array}{l}\text { Tamim et } \\
\text { al., (2016) }\end{array}$} \\
\hline & & $E F=1$ & Baseline data & \\
\hline & & $1 \leq \mathrm{EF}<1.5$ & $\begin{array}{l}\text { Possible } \\
\text { anthropogenic } \\
\text { origin }\end{array}$ & \\
\hline & & $1.5 \leq E F<3$ & $\begin{array}{l}\text { Minor } \\
\text { enrichment }\end{array}$ & \\
\hline & & $3 \leq \mathrm{EF}<5$ & $\begin{array}{l}\text { Moderate } \\
\text { enrichment }\end{array}$ & \\
\hline & & $5 \leq \mathrm{EF}<10$ & $\begin{array}{l}\text { Severe } \\
\text { modification }\end{array}$ & \\
\hline & & $\mathrm{EF}>10$ & $\begin{array}{l}\text { Very severe } \\
\text { modification }\end{array}$ & \\
\hline \multirow{3}{*}{$\begin{array}{l}\text { Pollution load } \\
\text { index, PLI }\end{array}$} & \multirow{3}{*}{$\begin{array}{l}P L I=\left(C F_{1} \times C F_{2} \times \ldots C F_{n}\right)^{\frac{1}{n}} \\
\text { where, CF is the contamination } \\
\text { factor }\end{array}$} & $P L I=0$ & Perfection & \multirow{3}{*}{$\begin{array}{l}\text { Tomlinson } \\
\text { et al., } \\
(1980)\end{array}$} \\
\hline & & $P L I<1$ & Baseline level & \\
\hline & & PLI > 1 & Contaminated & \\
\hline \multirow{5}{*}{$\begin{array}{l}\text { Potential } \\
\text { ecological risk } \\
\text { factor, Eri }\end{array}$} & \multirow{5}{*}{$\begin{array}{l}E r^{i}=\operatorname{Tr}^{i} \times C F^{i} \text { where, } \operatorname{Tr}^{i} \text { is the } \\
\text { biological toxic metal response } \\
\text { factor }(\mathrm{Zn}=1, \mathrm{Ni}=5, \mathrm{Mn}=1, \mathrm{~Pb}=5 \text {, } \\
\mathrm{Cu}=5, \mathrm{Cr}=2 \text { and } \mathrm{Cd}=30 \text {; Islam et al., } \\
\text { 2017) and CF is the contamination } \\
\text { factor. }\end{array}$} & $E r^{i}<40$ & Low risk & \multirow{5}{*}{$\begin{array}{l}\text { Hakanson, } \\
(1980) \text {; } \\
\text { Khan et al. } \\
(2020)\end{array}$} \\
\hline & & $40 \leq E r^{i}<80$ & Moderate risk & \\
\hline & & $80 \leq \mathrm{Er}^{\mathrm{i}}<160$ & $\begin{array}{l}\text { Considerable } \\
\text { risk }\end{array}$ & \\
\hline & & $\begin{array}{l}160 \leq \mathrm{Er}^{\mathrm{i}}< \\
320\end{array}$ & High risk & \\
\hline & & $\mathrm{Er}^{\mathrm{i}} \geq 320$ & Very high risk & \\
\hline
\end{tabular}




\begin{tabular}{|c|c|c|c|c|}
\hline Indices & Mathematical expressions & Classification & $\begin{array}{l}\text { Contamination } \\
\text { degree }\end{array}$ & References \\
\hline \multirow{4}{*}{$\begin{array}{l}\text { Potential } \\
\text { ecological risk } \\
\text { index (RI) }\end{array}$} & \multirow{4}{*}{$\begin{array}{l}R I=\sum_{i=1}^{n} E r^{i} \text { where } E r^{\mathrm{i}} \text { is the } \\
\text { potential ecological risk factor. }\end{array}$} & $\mathrm{RI}<150$ & Low risk & \multirow{4}{*}{$\begin{array}{l}\text { Hakanson, } \\
(1980) \text {; } \\
\text { Khan et al. } \\
(2020)\end{array}$} \\
\hline & & $150 \leq \mathrm{Rl}<300$ & Moderate risk & \\
\hline & & $300 \leq \mathrm{Rl}<600$ & $\begin{array}{l}\text { Considerable } \\
\text { risk }\end{array}$ & \\
\hline & & $\mathrm{RI} \geq 600$ & High risk & \\
\hline \multirow{11}{*}{$\begin{array}{l}\text { Entropy Water } \\
\text { Quality Index } \\
\text { (EWQI) }\end{array}$} & $X_{i j}-\left(X_{i j}\right)_{\min }$ & EWQI<50 & $\begin{array}{l}\text { Excellent for } \\
\text { drinking }\end{array}$ & \multirow{11}{*}{$\begin{array}{l}\text { Shannon } \\
\text { (1948); } \\
\text { Ahmed et } \\
\text { al. (2021) }\end{array}$} \\
\hline & $Y_{i j}=\overline{\left(X_{i j}\right)_{\max }-\left(X_{i j}\right)_{\min }}$ & & & \\
\hline & $P_{i j}=\frac{Y_{i j}}{\sum_{i=1}^{m} Y_{i j}}$ & $\begin{array}{l}50 \leq \text { EWQI } \\
<100\end{array}$ & $\begin{array}{l}\text { Good for } \\
\text { drinking }\end{array}$ & \\
\hline & $e_{j}=-\frac{1}{\ln (m)} \sum_{i=1}^{m}\left(P_{i j} \ln P_{i j}\right)$ & & & \\
\hline & $1-e_{j}$ & $\begin{array}{l}100 \leq \mathrm{EWQI} \\
<150\end{array}$ & $\begin{array}{l}\text { moderate } \\
\text { (domestic, }\end{array}$ & \\
\hline & $\omega_{j}=\overline{\sum_{j=1}^{m}\left(1-e_{j}\right)}$ & & $\begin{array}{l}\text { irrigation, } \\
\text { industrial } \\
\text { usage) }\end{array}$ & \\
\hline & $q_{j}=\frac{C_{j}}{S_{j}} \times 100$ & & & \\
\hline & $E W Q I=\sum_{j=1}^{n} \omega_{j} q_{j}$ & & & \\
\hline & & $\begin{array}{l}150 \leq \mathrm{EWQI} \\
<200\end{array}$ & $\begin{array}{l}\text { poor (not } \\
\text { suitable for } \\
\text { drinking) }\end{array}$ & \\
\hline & \multirow{2}{*}{$\begin{array}{l}\text { Where, } X, Y, P, e, \omega, q, C \text { and } S \text { are } \\
\text { analytical parameters, standard } \\
\text { grade value, analyzed parameter } \\
\text { index, information entropy, entropy } \\
\text { weight, obtained data and standard } \\
\text { reference data, respectively. }\end{array}$} & & & \\
\hline & & $E W Q I \geq 200$ & $\begin{array}{l}\text { extremely poor } \\
\text { (unacceptable) }\end{array}$ & \\
\hline
\end{tabular}

\subsection{Self-organizing map (SOM) analysis}

Kohonen (1982) pioneered for visualizing and clustering learning based algorithm to solve non-linear issue, which is recognized as self-organizing map (SOM) analysis (Wang et al. 2020). In general, artificial neural network (ANN) method is used for imagining multi-dimensional datasets into lower-dimensional image (Céréghino et al. 2009). After training stage, SOM can rapidly make a map using the new datasets.

Furthermore, having some random components based on training and identical topology it can show different results (Wehrens, 2009; Lenard et al., 1999).

In our work, SOM model was done for the assessment of surficial water and sediment samples of Wainivasi River, Fiji. SOM model provides a good graphical image of association between parameters. To visualize positive association, it exhibits analogous gradient pattern while anti-parallel pattern depicts for negative association. To develop the graphical representation, projection in two-dimensional datasets is the calculation 
grid size in the self-learning procedure (Kohonen et al., 2001; Park et al., 2003). However, the k-means process is a robust tool for clustering SOM model (Hentati et al., 2010; Jin et al., 2011). To estimate the number of SOM nodes, heuristic formula was adopted (Vesanto and Alhoniemi, 2000; Li et al., 2019).

$m=5 \sqrt{ } n(1)$

Here, $m$ is the SOM node number's and $\mathrm{n}$ is the input dataset number's (Vesanto et al., 2000).

By using the SOM analysis to the log-transformed and standardized the analyzed datasets $(n=32$ for sediment and water) 49( 42) output neurons were acquired. A total of 49 neurons were selected according to the heuristic Eq. (1) (Vesanto and Alhoniemi 2000). The neurons are represented on 9'7 rectangular grids with 49 neurons in this work. The details procedure of SOM analysis can be found elsewhere (Kumar et al., 2021a) and SOM map was prepared using MATLAB R2020a platform through neural clustering toolbox.

\subsection{Statistical analyses}

The multivariate statistical analyses such as Principal component analysis (PCA) and cluster analysis (CA) were carried out to detect plausible sources using Statistical Package for the Social Sciences (SPSS, version 23) and Origin Pro, (version 2015). To avoid the uncertainty of the PTEs distribution, Kolmogorov-Smirnov (K-

S) and Shapiro-Wilk (S-W) tests were employed by SPSS (SPSS, IBM, USA). PCA and one-way ANOVA test were executed at the significant level of $p \leq 0.05$. Cluster analysis was adopted to detect the likelihood of the similarity of the PTEs in this work (Saha et al., 2020). It is very popular and convenient multivariate approach that can handle the dataset based on the initial features. The relevant graphs were plotted using Origin Pro (version 2015) and Metlab (version 2017). Since the study sites and data were not large in size, the inverse distance weighted interpolation model was adopted for the spatial map of the PTEs for environmental media such as water and sediment using ArcGIS (version 10.4) (Islam et al., 2018).

\section{Results And Discussion}

\subsection{Characteristics of potentially toxic elements in sediment and water}

The variation of different PTEs in sediment samples of Wainivesi River, Fiji is presented in Table 2. The average analysis of data (in $\mathrm{mgkg}^{-1}$ ) depicted an order of heavy metals accumulation in sediment that was $\mathrm{Fe}$ $(50417 \pm 16773)>\mathrm{Zn}(1013 \pm 1286)>\mathrm{Pb}(112 \pm 62)>\mathrm{Mn}(89 \pm 29)>\mathrm{Cr}(58 \pm 22)>\mathrm{Ni}(49 \pm 26)>\mathrm{Cu}(28 \pm 25)$ $>\mathrm{Co}(23 \pm 8)>\mathrm{Cd}(10 \pm 13)$ respectively. The data indicated that $\mathrm{Cd}$ was marginally accumulated in the sediments, while Fe got extreme enrichment in the river basin. The percentage of relative standard deviation (\%RSD) for the heavy metals distribution in sediments at different sampling points showed that abundance of $\mathrm{Co}, \mathrm{Fe}$ and $\mathrm{Mn}$ did not significantly vary, while the rest of the metals (i.e., $\mathrm{Cd}, \mathrm{Zn}, \mathrm{Co}, \mathrm{Pb}, \mathrm{Ni}$ and $\mathrm{Cr}$ ) significantly varied (\%RSD: 39-128\%). This study showed the metals were heterogeneously distributed at different sampling points suggesting the sources of these metals in sediments were mainly anthropogenic. The concentrations of the studied PTEs in the sediment samples were compared with the threshold values of the sediment quality guidelines (SQGs): Probable Effect Level (PEL), Threshold Effect Level (TEL), Severe Effect Level (SEL), Effect 
Range Low (ERL), Lowest Effect Level (LEL), and the Effects Range Medium (ERM) values (Persuad et al., 1993; Macdonald et al., 1996; US-EPA, 1999). 
Table 2

Potentially toxic elements $\left(\mathrm{mg} \mathrm{kg}^{-1}\right)$ in sediment samples of Wainivesi River, Tailevu, Fiji are characterized in terms of sediment quality guidelines (SQG) and are compared with those of previous literature studies.

\begin{tabular}{|c|c|c|c|c|c|c|c|c|c|}
\hline & $\mathrm{Cr}$ & Mn & $\mathrm{Fe}$ & Co & $\mathrm{Ni}$ & $\mathrm{Cu}$ & Zn & Cd & $\mathrm{Pb}$ \\
\hline \multicolumn{10}{|l|}{ This work } \\
\hline Mean $(n=24)$ & 58.5 & 89.0 & 50417.1 & 23.4 & 49.7 & 28.7 & 1013.4 & 10.2 & 112.8 \\
\hline $\operatorname{SD}(1 \sigma)$ & 22.5 & 29.3 & 16773.0 & 8.0 & 26.7 & 25.0 & 1286.6 & 13.0 & 62.9 \\
\hline RSD (\%) & 38.5 & 33.0 & 33.3 & 34.2 & 53.6 & 87.0 & 127.0 & 128.2 & 55.7 \\
\hline Median & 51.3 & 85.7 & 52743.8 & 21.7 & 45.5 & 18.8 & 386.1 & 3.0 & 106.1 \\
\hline Min. & 28.1 & 32.6 & 10720.5 & 11.7 & 14.9 & 7.9 & 175.5 & 1.3 & 42.8 \\
\hline Max. & 110.4 & 139.6 & 85015.2 & 42.1 & 94.0 & 103.2 & 4693.9 & 45.9 & 252.2 \\
\hline Error (\%) & $\begin{array}{l}0.5- \\
2.0\end{array}$ & $1-2$ & $0.5-1.5$ & $1-3$ & $2-8$ & $2-4$ & $2-5$ & $2-9$ & $5-10$ \\
\hline \multicolumn{10}{|c|}{$\begin{array}{l}\text { SQG Threshold } \\
\text { values }\end{array}$} \\
\hline $\mathrm{LEL}^{\mathrm{b}}$ & 26 & 460 & 20000 & & 16 & 16 & 120 & 0.6 & 31 \\
\hline $\mathrm{SEL}^{\mathrm{b}}$ & 110 & 1100 & 40000 & & 75 & 110 & 820 & 10 & 250 \\
\hline $\mathrm{TEL}^{\mathrm{c}}$ & 52.3 & & & & 15.9 & 18.7 & 124 & 0.68 & 30.2 \\
\hline$P E L^{c}$ & 160 & & & & 42.8 & 108 & 271 & 4.21 & 112 \\
\hline$E L^{d}$ & 81 & & & & 20.9 & 34 & 150 & 1.2 & 46.7 \\
\hline ERM $^{d}$ & 370 & & & & 51.6 & 270 & 410 & 9.6 & 218 \\
\hline TRV & 26 & & & & 16 & 16 & 110 & 0.6 & 31 \\
\hline \multicolumn{10}{|c|}{$\begin{array}{l}\text { SQG-Characterization } \\
(\%)^{f}\end{array}$} \\
\hline$<L E L$ & 0 & 100 & 4.2 & & 0 & 33.3 & 0 & 0 & 0 \\
\hline LEL-SEL & 95.8 & 0 & 20.8 & & 87.5 & 66.7 & 25 & 75 & 95.8 \\
\hline >SEL & 4.2 & 0 & 75.0 & & 12.5 & 0 & 75 & 25 & 4.2 \\
\hline
\end{tabular}

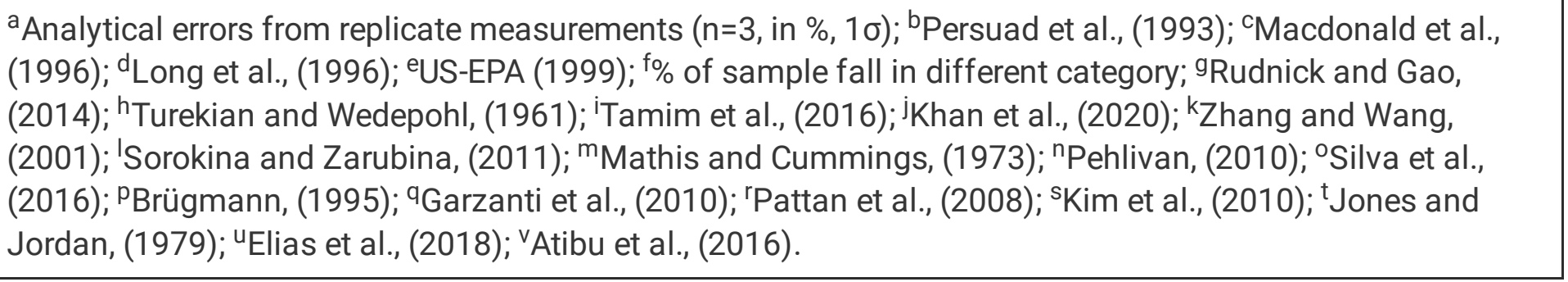




\begin{tabular}{|c|c|c|c|c|c|c|c|c|c|}
\hline & $\mathrm{Cr}$ & Mn & $\mathrm{Fe}$ & Co & $\mathrm{Ni}$ & $\mathrm{Cu}$ & Zn & Cd & $\mathrm{Pb}$ \\
\hline$<T E L$ & 58.3 & & & & 8.3 & 45.8 & 0 & 0 & 0 \\
\hline TEL-PEL & 41.7 & & & & 33.3 & 54.2 & 29.2 & 62.5 & 50 \\
\hline$>P E L$ & 0 & & & & 58.3 & 0 & 70.8 & 37.5 & 50 \\
\hline$<$ ERL & 79.2 & & & & 50 & 75 & 0 & 0 & 12.5 \\
\hline ERL-ERM & 20.8 & & & & 8.3 & 25 & 54.2 & 75 & 79.2 \\
\hline$>$ ERM & 0 & & & & 41.7 & 0 & 45.8 & 25 & 8.3 \\
\hline \multicolumn{10}{|l|}{ Lit. data } \\
\hline UCC & 92 & 775 & 39000 & & 47 & 28 & 67 & 0.09 & 17 \\
\hline ASVh $^{h}$ & 90 & 850 & 47200 & & 68 & 45 & 95 & 0.3 & 20 \\
\hline $\begin{array}{l}\text { Buriganga river, } \\
\text { Bangladesh }\end{array}$ & 788 & 508 & 25000 & 10.5 & & 45 & 101 & & 25 \\
\hline $\begin{array}{l}\text { Turag river, } \\
\text { Bangladesh }^{j}\end{array}$ & 70 & 768 & 29000 & 12.0 & & & 780 & & \\
\hline Pearl river, Chinak & 71.4 & 908 & 19600 & 16.2 & 37.7 & 54.5 & 202 & & 97.1 \\
\hline Amur river, Russial & 36.3 & 768 & 25400 & 6.34 & 25.6 & 7.43 & 43.4 & 0.21 & 19.2 \\
\hline Ilinois river, $\mathrm{USA}^{\mathrm{m}}$ & 98.1 & 483 & & & 25.7 & 31.0 & 117 & 0.61 & 60 \\
\hline $\begin{array}{l}\text { Buyukmelen river, } \\
\text { Turkey }^{\text {n }}\end{array}$ & 169 & 1007 & 45500 & 20.7 & 323 & 30.6 & 63.7 & 0.12 & 12.1 \\
\hline $\begin{array}{l}\text { Catumbela river, } \\
\text { Angola }^{\circ}\end{array}$ & 26 & 620 & 26800 & 9 & 20 & & & & 19 \\
\hline Elbe river, Germany ${ }^{p}$ & 386 & 1230 & 33400 & 13 & 58 & 206 & 1190 & 7.3 & 122 \\
\hline $\begin{array}{l}\text { Brahmaputra river, } \\
\text { Bangladesh }\end{array}$ & 96.2 & 752 & 35500 & 10.5 & 30.4 & 17.2 & 54.1 & 0.7 & 19.5 \\
\hline $\begin{array}{l}\text { Godavari-Krishna } \\
\text { river, Indiar }\end{array}$ & 129 & 800 & 63500 & 30 & 84 & 91 & 151 & & \\
\hline Kumho river, Koreas & 99.7 & & & 20.9 & 97.6 & 125 & 298 & 1.67 & 149 \\
\hline \multicolumn{10}{|c|}{ 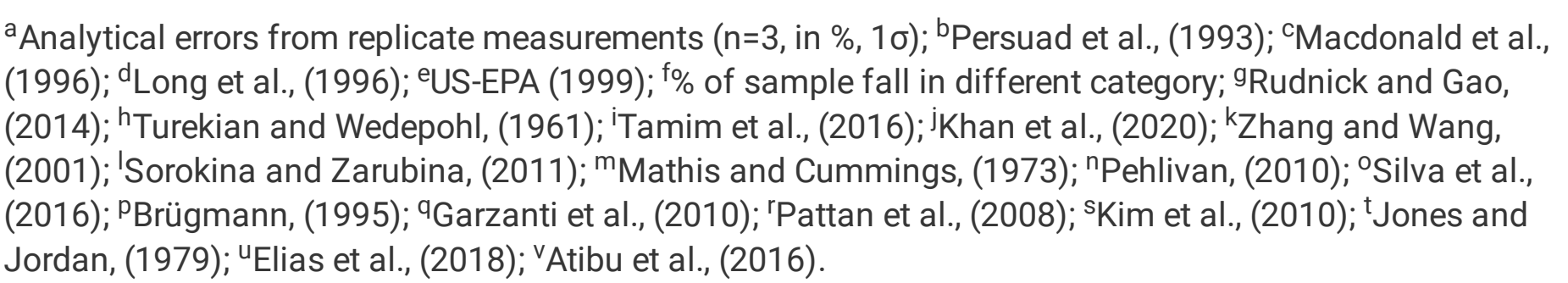 } \\
\hline
\end{tabular}




\begin{tabular}{|c|c|c|c|c|c|c|c|c|c|}
\hline & $\mathrm{Cr}$ & Mn & $\mathrm{Fe}$ & Co & $\mathrm{Ni}$ & $\mathrm{Cu}$ & $\mathrm{Zn}$ & Cd & $\mathrm{Pb}$ \\
\hline Liffey river, Ireland ${ }^{t}$ & & 496 & 26900 & 7 & 29 & 220 & 666 & 3.25 & \\
\hline $\begin{array}{l}\text { Linggi river, } \\
\text { Malaysiau }\end{array}$ & 33.3 & & 17710 & & 10.3 & 14.6 & 102.7 & 0.29 & 30.5 \\
\hline $\begin{array}{l}\text { Lubumbashi river, } \\
\text { Congov }^{v}\end{array}$ & 86.8 & 2920 & 45418 & 3774 & 55.4 & 14822 & 1415 & 42.9 & 1549 \\
\hline \multicolumn{10}{|c|}{ 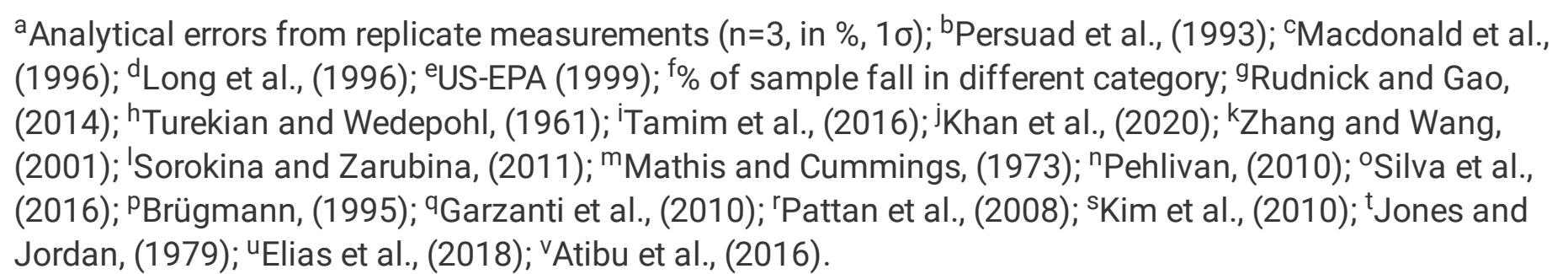 } \\
\hline
\end{tabular}

The average $\mathrm{Cr}$ concentration in sediment samples was noticed to be higher than LEL (Persuad et al., 1993), TEL (Macdonald et al., 1996), TRV (US-EPA, 1999), while lower than the SEL (Persuad et al., 1993), PEL (Macdonald et al., 1996), ERL (Long et al., 1996) and ERM (Long et al., 1996). This study revealed that $95.8 \%$ samples were fallen between the LEL and SEL, while $58.3 \%$ sample were below the TEL. Therefore, it could be suggested that the present levels of $\mathrm{Cr}$ in the study area does not have significant impact on the ecological health. However, if higher level of $\mathrm{Cr}$ would appear, then this could have adverse impact on the microbial community (Fashola et al., 2016). Nonetheless, the average $\mathrm{Cr}$ concentration was below than the maximum acceptable $\mathrm{Cr}$ concentration in surface soil and the reported $\mathrm{Cr}$ level $\left(486 \mathrm{mg} \mathrm{kg}^{-1}\right)$ in gold mine tailing in Oman (Abdul-Wahab, S.; Marikar, 2012). Subsequently, the average $\mathrm{Cr}$ concentration in sediment samples was lower than the several rivers sediments reported in literature (Tamim et al., 2016; Khan et al., 2020; Zhang and Wang, 2001; Mathis and Cummings, 1973; Pehlivan, 2010; Garzanti et al., 2010; Pattan et al., 2008); Kim et al., 2010), which indicating that the sediment in Wainivesi River, Fiji was not severely contaminated with $\mathrm{Cr}$.

This study revealed that the $100 \%$ Wainivesi River sediment for Mn concentration was much lower than the two SQGs threshold values (LEL and SEL) (Table 1), which was consistent with the reported results for different river sediment in the world: Bangladesh (Tamim et al., 2016), China (Zhang and Wang, 2001), Russia (Sorokina and Zarubina, 2011), Turkey (Pehlivan, 2010), Angola (Silva et al., 2016), Germany (Brügmann, 1995), Ireland (Jones and Jordan, (1979), Malaysia (Elias et al., 2018), Congo (Atibu et al., 2016). Therefore, it has been suggested that the sediments in the study area were free from Mn contamination with respect to the SQG threshold values. 
Nickel $(\mathrm{Ni})$ concentration in $12.5 \%$ and $58.3 \%$ of the samples were exceeded the SEL and PEL thresholds respectively Moreover, $87.5 \%$ of the samples were between LEL and SEL threshold and $33.3 \%$ of the samples were between TEL and PEL thresholds (Table 2). The average Ni concentration was much higher than all the threshold values (LEL, SEL, TEF, PEL, ERL, ERM and TRV) for the SQGs (Persuad et al., 1993; Macdonald et al., 1996; Long et al., 1996; US-EPA, 1999). These results showed that Ni may potential harmful to the sedimentdwelling organisms. It is noteworthy to mention that $\mathrm{Ni}$ have been shown to adversely interfere with the bacterial cells. Studies have shown that Ni can damage the bacterial cell by (1) substituting fundamental metal in metalloproteins; (2) connecting to synergist deposits of non-metalloenzymes; (3) and by inducing oxidative pressure that enhance DNA fragmentation (Fashola et al., 2016). However, the average Ni concentration for this study was found to be higher than the reported results for sediments in many countries in the world (Tamim et al., 2016; Zhang and Wang, 2001; Sorokina and Zarubina, 2011; Pehlivan, 2010; Silva et al., 2016; Brügmann, 1995; Jones and Jordan, 1979; Elias et al., 2018; Atibu et al., 2016). The higher level of Ni was observed in the study area because of gold mining as well as Ni exist in gold bearing ore as pyrrhotite $\left(\mathrm{Fe}_{(1-\mathrm{x})} \mathrm{S}\right)$, which can contain up to $5 \%$ of $\mathrm{Ni}$ (Fashola et al., 2016). In addition to gold mining, Ni may be acquired from the synthetic industry waste, burning, metallurgy, and metal plating (Palansooriya et al., 2020).

The average Cu concentration in the sediment samples was observed to be higher than LEL (Persuad et al., 1993), TEL (Macdonald et al., 1996), TRV (US-EPA, 1999), while lower than the SEL (Persuad et al., 1993), PEL (Macdonald et al., 1996), ERL (Long et al., 1996) and ERM (Long et al., 1996). This study revealed that $95.8 \%$ samples were fallen between the LEL and SEL thresholds, while $58.3 \%$ sample were below TEL thresholds. The average $\mathrm{Cu}$ concentration in the sediments for this study was in line with the reported mean concentration of unpolluted soil (5 to $70 \mathrm{mg} \mathrm{kg}^{-1}$ ) (Kabata-Pendias and Pendias, 2001) and lower than the Cu level (92.2 mg $\mathrm{kg}^{-1}$ ) in the gold mine tailings in Ghana (Bempah et al., 2013). However, the average Cu levels in Wainivesi River sediment (Fiji) was lower than the reported results of the river sediments in several countries in the world (Turekian and Wedepohl, 1961; Zhang and Wang, 2001; Sorokina and Zarubina, 2011; Mathis and Cummings, 1973; Silva et al., 2016; Garzanti et al., 2010; Pattan et al., 2008; Kim et al., 2010; Elias et al., 2018; Atibu et al., 2016).

Iron (Fe) concentration was found to be higher than many river sediments in the world: Bangladesh (Tamim et al., 2016), China (Zhang and Wang, 2001), Russia (Sorokina and Zarubina, 2011), Turkey (Pehlivan, 2010), Angola (Silva et al., 2016), Germany (Brügmann, 1995), Ireland (Jones and Jordan, (1979), Malaysia (Elias et al., 2018), Congo (Atibu et al., 2016). Subsequently, SQGs threshold values showed that $75 \%$ of the samples were higher than SEL and $20 \%$ were between LEL to SEL, which indicating that Fe may likely cause potential harm to sediment-dwelling organisms. High level of Fe might be resulting from industrial activities, especially mining industry.

Zinc (Zn) concentration in sediment samples was ranged from 175.5 to $4693.9 \mathrm{mg} \mathrm{kg}^{-1}$ with an average value of $1013.4 \mathrm{mg} \mathrm{kg}^{-1}$, which was much higher than the entire threshold values (LEL, SEL, TEF, PEL, ERL, ERM, TRV) for sediment quality guidelines (Table 2). However, Zn concentration in $75 \%, 71 \%$ and $46 \%$ of the samples were exceeded the SEL, PEL and ERM thresholds respectively. Moreover, $29.2 \%$ of the samples were between TEL and PEL threshold and $54.2 \%$ of the samples were between ERL and ERM thresholds. Zinc speciation is significant in deciding its harmfulness to microorganisms (Fashola et al., 2016). High 
concentrations of $\mathrm{Zn}$ show diverse inhibitory or harmful impact on cell activity and bacterial cells development. Furthermore, it was reported the present of high Zn concentration, nitrification processes catalized by Nitrosospira sp. was reduced 20\% (Mertens et al., 2007). Therefore, it has been suggested that $\mathrm{Zn}$ has significant impact on the environment and ecological health. The average $\mathrm{Zn}$ concentration in sediments for this study was several folds higher than the reported results (8.9 to $65.7 \mathrm{mg}-\mathrm{Zn} \mathrm{kg}^{-1}$ ) in the gold mine

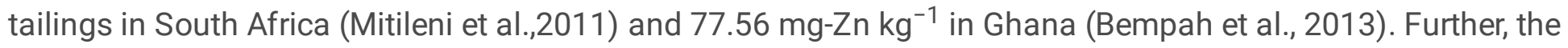
average $\mathrm{Zn}$ concentration for this study was found to be higher than the reported results for the river sediments in many countries in the world (Tamim et al., 2016; Zhang and Wang, 2001; Sorokina and Zarubina, 2011; Pehlivan, 2010; Silva et al., 2016; Brügmann, 1995; Jones and Jordan, 1979; Elias et al., 2018; Atibu et al., 2016). This may have occur due to possible Zn leaching from gold ore bodies (Fashola et al., 2016), as Zn occurs in gold ore bodies in the form sphalerite (ZnS), which is often associated with galena; and thereby accumulating in the sediments (Emenike et al., 2020).

A wide range of $\mathrm{Cd}$ concentration ( 1.3 to $45.9 \mathrm{mg} \mathrm{kg}^{-1}$ ) was found in the study area with an average value of $10.2 \mathrm{mg} \mathrm{kg}^{-1}$, which was higher than the typically $\mathrm{Cd}$ concentration $\left(1 \mathrm{mg} \mathrm{kg}^{-1}\right)$ in unpolluted soil (USEPA, 2001); and the reported Cd concentration (6.4 to $11.7 \mathrm{mg} \mathrm{kg}^{-1}$ ) in gold mine tailings in Tanzania (Bitala et al., 2009). On the other hand, the average $C d$ concentration was found to be higher than the entire threshold values (LEL, SEL, TEF, PEL, ERL, ERM, TRV) for the SQGs (Persuad et al., 1993; Macdonald et al., 1996; Long et al., 1996; US-EPA, 1999) guidelines (Table 2). Furthermore, Cd concentration surpassed the SEL, PEL and ERM standards in $25 \%, 37.5 \%$ and $43 \%$ of the samples, respectively. Subsequently, $62.5 \%$ of the samples were between ERL and ERM thresholds; and 75\% of the samples were between ERL and ERM. The outcomes represent the probability of destructive impacts caused by $\mathrm{Cd}$ on the biota. Cadmium is a harmful heavy metal to most organisms and it influences numerous metabolic activities of soil microorganisms like nitrogen mineralization, carbon mineralization, $\mathrm{CO}_{2}$ evolution and protein activities (USEPA, 2001). It was observed that the average $\mathrm{Cd}$ concentration for this study was found to be higher than the reported results for the sediments in many countries in the world (Tamim et al., 2016; Zhang and Wang, 2001; Sorokina and Zarubina, 2011; Pehlivan, 2010; Silva et al., 2016; Brügmann, 1995; Jones and Jordan, 1979; Elias et al., 2018; Atibu et al., 2016). A few anthropogenic exercises bring Cd into the environment. Gold mining activities is one of them as well as it occurs in gold bearing ore bodies as an isometric minor component in sphalerite and its focus relies upon the grouping of the sphalerite in the mineral body (Fashola et al., 2016).

The average $\mathrm{Pb}$ concentration in sediment was found to be lower than the threshold values of SEL, ERM, while higher than that of the LEL, TEL, PEL, ERL, and TRV. Pb concentration in $50 \%$ of the samples was greater than the PEL threshold; while $95.8 \%$ of the samples were between LEL and SEL thresholds. Moreover, $50 \%$ of the samples were between TEL and PEL thresholds and $79.2 \%$ of the samples were between, ERL and ERM thresholds (Table 2). Like as other fundamental divalent metals $\left(\mathrm{Mn}^{2+}\right.$ and $\left.\mathrm{Zn}^{2+}\right), \mathrm{Pb}^{2+}$ might interfere with nucleic acids, proteins, and the alterations of the osmotic balance in the bacterial cells (Fashola et al., 2016). Therefore, excessive $\mathrm{Pb}$ in sediments might have adverse impact on ecological health (Rahman et al., 2014; Rahman et al., 2021). The average $\mathrm{Pb}$ concentration for this study was found to be higher than the $\mathrm{Pb}$ in surface soils $\left(32 \mathrm{mg} \mathrm{kg}^{-1}\right)$ worldwide average (Kabata-Pendias and Pendias, 2001) but was in line for $\mathrm{Pb}$ concentration (80 to $510 \mathrm{mg} \mathrm{kg}^{-1}$ ) in gold mine tailing (Ogola et la., 2002). The average $\mathrm{Pb}$ concentration was found to be greater than the river sediments in Bangladesh (Tamim et al., 2016), China (Zhang and Wang, 
2001), Russia (Sorokina and Zarubina, 2011), Turkey (Pehlivan, 2010), Angola (Silva et al., 2016), Germany (Brügmann, 1995), Ireland (Jones and Jordan, (1979), Malaysia (Elias et al., 2018) and Congo (Atibu et al., 2016). This high $\mathrm{Pb}$ could be due the excessive use of gasoline additives, pesticides, as well as chemical fertilizers (Aboud and Nandini, 2009), sand extraction (Madzin et al., 2015) and mining activities (Emenike et al., 2020). The excessive $\mathrm{Pb}$ in the study area may be attributed to the gold mining since $\mathrm{Pb}$ occurs in the form of galena (PbS) in gold ore (Ogola et la., 2002).

The PTEs concentrations in surface water of Wainivesi River, Fiji were analyzed by AAS-based analytical technique and the statistics data (i.e., minimum, median, mean, maximum, standard deviation) for the each studied metal was presented in Table 3, in comparison with the different reported results in the literature and the threshold values set by different recommended bodies (ECR, 1997; WHO, 2011; EU, 2003; USEPA, 2001; EPA, 2001. The average metal contents in the water samples were showed the following increasing trend: $\mathrm{Cd}$ $(12 \pm 10)<\mathrm{Co}(34 \pm 15)<\mathrm{Mn}(45 \pm 32)<\mathrm{Cu}(47 \pm 38)<\mathrm{Cr}(104 \pm 24)<\mathrm{Ni}(115 \pm 20)<\mathrm{Zn}(183 \pm 295)<\mathrm{Pb}$ $(190 \pm 16)<\mathrm{Fe}(1632 \pm 1335) \mu \mathrm{g} \mathrm{L}^{-1}$ respectively. The \%RSD for the heavy metals distribution in water samples at different sampling points in Wainivesi River, Fiji showed a wide ranged (45-161\%) for the metals of $\mathrm{Co}, \mathrm{Ni}, \mathrm{Cu}, \mathrm{Zn}, \mathrm{Cd}$ and $\mathrm{Pb}$; whereas \%RSD values for rest of the metals ( $\mathrm{Cr}, \mathrm{Mn}$ and $\mathrm{Fe}$ ) were not varied significantly. However, it has been observed that the sources of most PTEs were anthropogenic origin. Moreover, our results indicated that the most of heavy metals were not homogeneously distributed in the study area. 
Table 3

Potentially toxic elements $\left(\mu \mathrm{g} \mathrm{L}^{-1}\right)$ in water samples of Wainivesi River, Tailevu, Fiji are compared with those of threshold values and previous literature studies along with the water quality appraisal (entropy water quality index, EWQI).

\begin{tabular}{|c|c|c|c|c|c|c|c|c|c|c|}
\hline & $\mathrm{Cr}$ & $\mathrm{Mn}$ & $\mathrm{Fe}$ & Co & $\mathrm{Ni}$ & $\mathrm{Cu}$ & $\mathrm{Zn}$ & Cd & $\mathrm{Pb}$ & EWQI \\
\hline \multicolumn{11}{|l|}{ This work } \\
\hline W-1 & 55.0 & 96 & 610 & 4.0 & 140 & 93.0 & 753 & 18 & 153 & 206 \\
\hline W-2 & 80.0 & 77 & 870 & 23 & 125 & 74.0 & 553 & 6.0 & 204 & 185 \\
\hline W-3 & 105 & 5.0 & 610 & 27 & 72.0 & 10.0 & 32.0 & 5.0 & 194 & 148 \\
\hline W-4 & 118 & 58 & 4260 & 35 & 105 & 107 & 35.0 & 25 & 199 & 468 \\
\hline W-5 & 113 & 10 & 570 & 44 & 117 & 14.0 & 22.0 & 8.0 & 189 & 160 \\
\hline W-6 & 118 & 27 & 1720 & 49 & 113 & 21.0 & 21.0 & 5.0 & 204 & 224 \\
\hline W-7 & 122 & 32 & 1400 & 45 & 119 & 31.0 & 22.0 & 3.0 & 189 & 191 \\
\hline W-8 & 122 & 55 & 2940 & 46 & 128 & 24.0 & 23.0 & 26 & 189 & 390 \\
\hline Mean $(n=8)$ & 104 & 45 & 1623 & 34 & 115 & 46.8 & 183 & 12 & 190 & 247 \\
\hline $\operatorname{SD}(1 \sigma)$ & 24 & 32 & 1335 & 15 & 20 & 38.5 & 295 & 10 & 16 & 117 \\
\hline RSD (\%) & 23.2 & 71.3 & 82.3 & 45.1 & 17.6 & 82.3 & 161.7 & 79.2 & 8.6 & 47.5 \\
\hline Median & 116 & 44 & 1135 & 40 & 118 & 27.5 & 27.5 & 7.0 & 192 & 199 \\
\hline Min. & 55.0 & 5.0 & 570 & 4.0 & 72 & 10.0 & 21.0 & 3.0 & 153 & 148 \\
\hline Max. & 122 & 96 & 4260 & 49 & 140 & 107 & 753 & 26 & 204 & 468 \\
\hline $\begin{array}{l}\text { Error }(\%, \text { RSD } \\
\text { of } n=3)^{a}\end{array}$ & $3-7 \%$ & $5-8 \%$ & $2-5 \%$ & $\begin{array}{l}5- \\
10 \%\end{array}$ & $4-9 \%$ & $\begin{array}{l}7- \\
10 \%\end{array}$ & $3-8 \%$ & $\begin{array}{l}8- \\
12 \%\end{array}$ & $3-5 \%$ & \\
\hline \multicolumn{11}{|l|}{$\begin{array}{l}\text { Threshold } \\
\text { values }\end{array}$} \\
\hline $\mathrm{ECR}^{\mathrm{b}}$ & 50 & 100 & $\begin{array}{l}300- \\
1000\end{array}$ & & 100 & 1000 & 5000 & 5 & 50 & \\
\hline $\mathrm{WHO}^{\mathrm{C}}$ & 50 & 100 & 300 & & 70 & 2000 & 3000 & 3 & 10 & \\
\hline
\end{tabular}

${ }^{a}$ Analytical errors from replicate measurements $(n=3$, in \%, $1 \sigma) ;{ }^{b} E C R$ (Environment Conservation Rules, Bangladesh), (1997); 'WHO (World Health Organization), (2011); ${ }^{\mathrm{d} B I S}$ (Bureau of Indian Standard), (2012); eEU (European Union), (2003); fUSEPA (United States Environmental Protection Agency) (2009); ${ }^{\text {EEPA }}$ (Environmental Protection Agency, Ireland), (2001); ${ }^{\mathrm{h}} \mathrm{MHC}$ (Ministry of Health of PR China), (2007); 'Li and Zhang, (2010); jMKSTPR (Meghna, Kartoya, Sitalakha, Teesta, Pashur, Rupsha river): Islam et al., (2020); kBhuiyan et al., (2015); 'Bhuyan and Bakar, (2017); ${ }^{\mathrm{m}}$ Gao et al., (2019); ${ }^{\mathrm{n}}$ Wang et al., (2017); ${ }^{\circ}$ Meng et al., (2016); ${ }^{\mathrm{P} X i a o}$ et al., (2014); ${ }^{\mathrm{G}} \mathrm{Giri}$ and Singh, (2014; ' ${ }^{\mathrm{T}}$ Thuong et al., (2013); ${ }^{\mathrm{S}}$ Eneji et al., (2012); ${ }^{\mathrm{t}}$ Varol and Şen, (2012); " Dragun et al., (2009); ' Markich and Brown, (1998); 'WKazi et al., (2009). 


\begin{tabular}{|c|c|c|c|c|c|c|c|c|c|c|}
\hline & $\mathrm{Cr}$ & Mn & $\mathrm{Fe}$ & Co & $\mathrm{Ni}$ & $\mathrm{Cu}$ & $\mathrm{Zn}$ & $\mathrm{Cd}$ & $\mathrm{Pb}$ & EWQI \\
\hline $\mathrm{BIS}^{\mathrm{d}}$ & 50 & 100 & 300 & & 20 & 50 & 5000 & 3 & 10 & \\
\hline$E U^{e}$ & 50 & 50 & 200 & & 20 & 2000 & 5000 & 5 & 10 & \\
\hline USEPA $^{f}$ & 100 & 50 & 300 & & 52 & 1300 & 5000 & 5 & 15 & \\
\hline $\mathrm{EPA}^{\mathrm{g}}$ & 50 & 50 & 200 & & 20 & 2000 & & 5 & 10 & \\
\hline $\mathrm{MHC}^{\mathrm{h}}$ & 50 & 100 & 300 & & 20 & 1000 & 1000 & 5 & 10 & \\
\hline \multicolumn{11}{|l|}{ Lit. Data } \\
\hline $\begin{array}{l}\text { Han River, } \\
\text { China }^{i}\end{array}$ & 8.1 & 30.7 & 30.6 & & 1.7 & 13.4 & & 2.3 & 9.3 & \\
\hline $\begin{array}{l}\text { MKSTPR } \\
\text { River, } \\
\text { Bangladesh }\end{array}$ & 27.7 & 233.8 & 2475.8 & & 13.5 & & 53.2 & 6.2 & 12.4 & \\
\hline $\begin{array}{l}\text { Buriganga } \\
\text { River, } \\
\text { Bangladeshk }\end{array}$ & 114.0 & 157.0 & 612.0 & 199.0 & 150.0 & & 332.0 & 59.0 & 119.0 & \\
\hline $\begin{array}{l}\text { Halda River, } \\
\text { Bangladesh' }\end{array}$ & 30.0 & 160.0 & & 50.0 & 410.0 & & 35.0 & 40.0 & 30.0 & \\
\hline $\begin{array}{l}\text { Major Rivers, } \\
\text { China }^{m}\end{array}$ & 6.5 & 2.3 & & 0.1 & 2.0 & & 0.8 & & 0.2 & \\
\hline $\begin{array}{l}\text { Huaihe } \\
\text { Rivers, China }{ }^{n}\end{array}$ & 23.1 & 49.0 & 441.0 & 42.5 & 46.2 & & 10504 & 61.7 & 155.0 & \\
\hline $\begin{array}{l}\text { Dan River, } \\
\text { China }^{\circ}\end{array}$ & 0.1 & 6.7 & 2.7 & 0.2 & 1.7 & 0.1 & 7.8 & 0.7 & & \\
\hline $\begin{array}{l}\text { Tarim River, } \\
\text { China }^{\mathrm{p}}\end{array}$ & 0.43 & 16.5 & 61.9 & 0.1 & 1.8 & & 7.1 & & 0.5 & \\
\hline $\begin{array}{l}\text { Subarnarekha } \\
\text { River, India } 9\end{array}$ & 0.89 & 12.0 & 134.0 & 0.6 & 25.2 & 16.6 & & & & \\
\hline
\end{tabular}

\footnotetext{
${ }^{a}$ Analytical errors from replicate measurements $(n=3$, in \%, $1 \sigma) ;{ }^{b} E C R$ (Environment Conservation Rules, Bangladesh), (1997); 'WHO (World Health Organization), (2011); ${ }^{\mathrm{d} B I S}$ (Bureau of Indian Standard), (2012); eEU (European Union), (2003); fUSEPA (United States Environmental Protection Agency) (2009); gEPA (Environmental Protection Agency, Ireland), (2001); ${ }^{\mathrm{h}} \mathrm{MHC}$ (Ministry of Health of PR China), (2007); 'Li and Zhang, (2010); jMKSTPR (Meghna, Kartoya, Sitalakha, Teesta, Pashur, Rupsha river): Islam et al., (2020); kBhuiyan et al., (2015); 'Bhuyan and Bakar, (2017); ${ }^{\mathrm{m}}$ Gao et al., (2019); ${ }^{\mathrm{n}}$ Wang et al., (2017); ${ }^{\circ}$ Meng et al., (2016); ${ }^{\mathrm{P} X i a o}$ et al., (2014); ${ }^{\mathrm{q}} \mathrm{Giri}$ and Singh, (2014; ${ }^{\mathrm{T}}$ Thuong et al., (2013); ${ }^{\mathrm{S}}$ Eneji et al., (2012); ${ }^{\mathrm{t}}$ Varol and Şen, (2012); " Dragun et al., (2009); ' Markich and Brown, (1998); 'WKazi et al., (2009).
} 


\begin{tabular}{|c|c|c|c|c|c|c|c|c|c|c|}
\hline & $\mathrm{Cr}$ & $\mathrm{Mn}$ & $\mathrm{Fe}$ & Co & $\mathrm{Ni}$ & $\mathrm{Cu}$ & $\mathrm{Zn}$ & Cd & $\mathrm{Pb}$ & EWQI \\
\hline $\begin{array}{l}\text { Lich River, } \\
\text { Vietnam }\end{array}$ & 2.9 & 216.2 & & & 7.6 & 4.5 & 51.1 & & 8.1 & \\
\hline $\begin{array}{l}\text { Benue River, } \\
\text { Nigeriass }^{\text {s. }}\end{array}$ & 38.1 & 181.0 & 751.0 & & & & 78.7 & 52.0 & 207.0 & \\
\hline $\begin{array}{l}\text { Tigris River, } \\
\text { Turkey }^{t}\end{array}$ & $<5$ & 467.0 & 388.0 & 111.0 & 72.0 & 165.0 & 37.0 & 1.4 & 0.3 & \\
\hline $\begin{array}{l}\text { Sava River, } \\
\text { Croatia }^{u}\end{array}$ & 0.3 & 3.4 & 12.6 & 0.064 & 0.6 & 0.5 & 2.27 & 0.011 & 0.055 & \\
\hline $\begin{array}{l}\text { Hawkesbury- } \\
\text { Nepean River, } \\
\text { Australiav }\end{array}$ & & 52.0 & 268.0 & 0.2 & 0.26 & 0.8 & 0.88 & 0.045 & 0.111 & \\
\hline $\begin{array}{l}\text { Manchar } \\
\text { Lake, } \\
\text { Pakistanw }\end{array}$ & 7.64 & 72.6 & 2960 & 38.94 & 35 & 18.9 & 730 & 5.3 & 82.4 & \\
\hline \multicolumn{11}{|l|}{$\begin{array}{l}\text { Parameters } \\
\text { for EWQI }\end{array}$} \\
\hline $\begin{array}{l}\text { Standard } \\
\text { data }\left(S_{j}\right)^{c}\end{array}$ & 50 & 100 & 300 & & 70 & 2000 & 3000 & 3 & 10 & \\
\hline $\begin{array}{l}\text { Information } \\
\text { entropy }\left(e_{j}\right)\end{array}$ & 0.919 & 0.836 & 0.668 & & 0.925 & 0.755 & 0.384 & 0.755 & 0.930 & \\
\hline $\begin{array}{l}\text { Entropy } \\
\text { weight }\left(\omega_{\mathrm{j}}\right)\end{array}$ & 0.045 & 0.090 & 0.182 & & 0.041 & 0.134 & 0.337 & 0.134 & 0.038 & \\
\hline \multicolumn{11}{|c|}{ 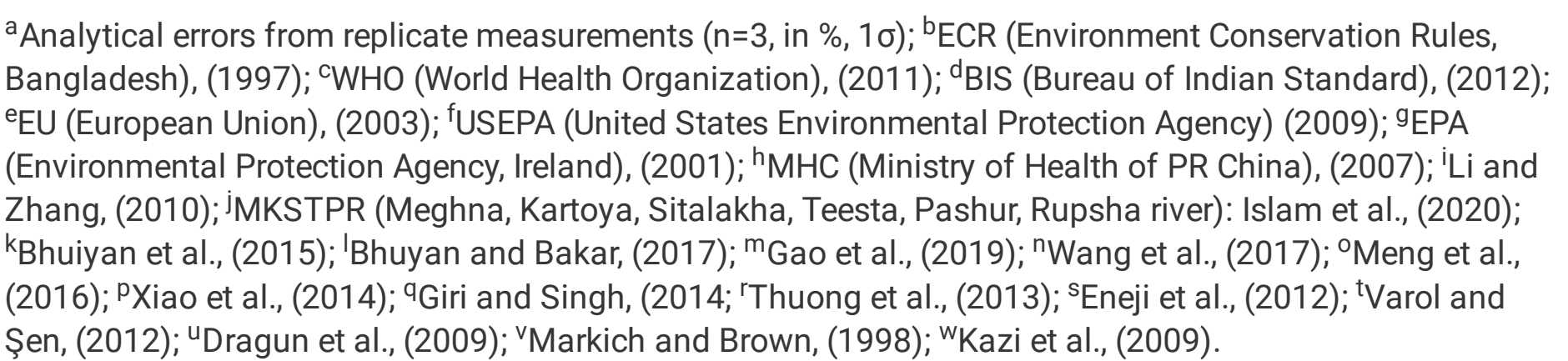 } \\
\hline
\end{tabular}

The $\mathrm{pH}$ of the water samples was within the standard level set by the WHO (pH: 6.5-8.5), showing alkaline in nature (Table S1). The low organic components may trigger the probable high $\mathrm{pH}$ values at these respective locations in the designated area. The average electrical conductivity (EC) (our work: 0.10; limit values: 0.25-2.5 $\mathrm{mS} \mathrm{cm}{ }^{-1}$ ) and total dissolved solids (TDS) (our work: 0.065 ; limit values: $1 \mathrm{~g} \mathrm{~L}^{-1}$ ) were compared to those of suggested standard limit values set by international laws (WHO, 2011; ECR, 1997; EU, 1998; EPA, 2001) while dissolved oxygen (DO) (our work: 9.49; limit values: $6 \mathrm{mg} \mathrm{L}^{-1}$ ) were comparatively greater than the permissible levels (ECR, 1997). The comparison of PTEs in the Wainivesi River, Fiji with the baseline values of the current work river and other rivers across the globe are displayed in Table 3. 
The maximum $\mathrm{Cr}$ concentration $\left(122 \mu \mathrm{g} \mathrm{L}^{-1}\right)$ was found at the sampling points of W7 ranging from $55-122 \mu \mathrm{g}$ $\mathrm{L}^{-1}$. This study showed that $\mathrm{Cr}$ concentration for $100 \%$ of the sampling points in Wainivesi River was exceeded the threshold values recommended by Environment Conservation Rules, Bangladesh (ECR, 1997), World Health Organization (WHO, 1996), Bureau of Indian Standard (BIS, 2012), European Union (EU, 2003), Environmental Protection Agency, Ireland (EPA, 2001) and Ministry of Health of PR China (MHC, 2007). Subsequently, the average $\mathrm{Cr}$ concentration was observed higher than the reported results for river water in Bangladesh (Islam et al., 2020; Bhuyan and Bakar, 2017), China (Li and Zhang, 2010; Gao et al., 2019; Wang et al., 2017; Meng et al., 2016; Xiao et al., 2014), India (Giri and Singh, 2014), Vietnam (Thuong et al., 2013), Nigeria (Eneji et al., 2012), Turkey (Varol and Şen, 2012), Crotia (Dragun et al., 2009), Pakistan (Kazi et al., 2009). Therefore, it has been suggested that Wainivesi River is not suitable for drinking purposes. A reasonable cause of $\mathrm{Cr}$ in these locations might be disintegrated in ultramafic volcanic stone by enduring and diagenesis measures, which prompted to the elevated Cr levels (Zhitkovich, 2011).

The average Mn concentration ( $45 \mu \mathrm{g} \mathrm{L}^{-1}$ ) in surface water samples of Wainivesi River was found to be below than the threshold values recommended by the several organizations (ECR, 1997; WHO, 1996; BIS, 2012; EU, 2003; EPA, 2001; MHC, 2007). However, the maximum Mn concentration was found at the sampling point of W1, which is near to mine area and $50 \%$ water samples (W8, W4, W2, and W1) contained higher Mn concentration than that of the recommended bodies. However, the current climatic condition in this area upholds Mn transport as manganese hydroxide by framing carbonate layers (Maata and Singh, 2008). While pH esteems from 6.62 to 7.83 in a large portion of the waters, the dissolvability of Mn will in general improve (Islam et al., 2020b). In view of this proof, higher Mn concentrations found in surface waters may have a geogenic beginning, related with chemical weathering and disintegration of mineral in the bedrocks (Kumara et al., 2021). The ranking order of the average Mn concentration in surface water was $W 3<W 5<W 6<W 7<$ $\mathrm{W} 8<\mathrm{W} 4<\mathrm{W} 2<\mathrm{W} 1$ respectively ranging from 5 to $96 \mu \mathrm{L}^{-1}$. The average Mn concentration in surface water was in line with the reported result for the Nasivi River (Fiji), which is located near the Vatukoula Goldmine region (VGR), Fiji (Kumara et al., 2021).

The Ni concentration in 8 different sampling points was found in a wide range (72 to $140 \mu \mathrm{g} \mathrm{L}^{-1}$ ) and $>90 \%$ water sample contained higher Ni concentration compared to the threshold values set by the ECR (1997), WHO (1996), EU (2003), EPA (2001). The finding of this study is consistent with the reported result for the Nasivi River (Fiji), which is located near the Vatukoula Goldmine region (VGR), Fiji (Kumara et al., 2021). Similar to $\mathrm{Mn}$, the highest Ni concentration was found at the sampling point of W1, which was 2 times higher than the drinking water guideline value set by WHO (1996). Furthermore, the average Ni concentration was found to be higher than the several river waters in the world: China (Han River: Li et al., 2010; Major Rivers: Gao et al., 2019; Huaihe River: Wang et al., 2017; Dan River: Meng et al., 2016; Tarin River: Giri et al., 2014), India (Giri and Singh, 2014), Vietnam (Thuong et al., 2013), Nigeria (Eneji et al., 2012), Turkey (Varol and Şen, 2012), Crotia (Dragun et al., 2009), Pakistan (Kazi et al., 2009). The high level of Ni in Wainivesi River water could be sue to leaching of Ni from gold bearing ore as pyrrhotite $\left(\mathrm{Fe}_{(1-x)} \mathrm{S}\right)$, which can contain up to $5 \%$ of Ni (Fashola et al., 2016).

The highest $\mathrm{Zn}$ concentration $\left(753 \mu \mathrm{g} \mathrm{L}{ }^{-1}\right)$ in surface water found at the sampling point of W1, while the lowest $\mathrm{Zn}$ concentration $\left(21 \mu \mathrm{g} \mathrm{L}^{-1}\right)$ was found at the sampling point of W6 having an average value of 183

Page 22/46 
$\mu \mathrm{g} \mathrm{L}^{-1}$. The ranking order for Zn concentration in the study area was W8 $<\mathrm{W} 2<\mathrm{W} 4<\mathrm{W} 1<\mathrm{W} 6<\mathrm{W} 7<\mathrm{W} 3<$ W5 respectively. The average $Z n$ concentration in Wainivesi River waters found to be below than the threshold values set by the ECR (1997), WHO (1996), BIS (2012), EU (2003), EPA (2001) and MHC (2007). This finding suggested that the surface water in the study area might be free form $\mathrm{Zn}$ contamination as well there is no coal combustion and waste incineration in the study area, which might be prime sources of $\mathrm{Zn}$ in surface water/environment (Rahman et al., 2021).

This study revealed that $>90 \%$ and $>100 \%$ water samples of Wainivesi River, Fiji contained higher $\mathrm{Cd}$ and $\mathrm{Pb}$ level compared to the threshold values (Table 2) set by the ECR (1997), WHO (1996), BIS (2012), EU (2003), EPA (2001) and MHC (2007). Among all the studied heavy metals, these two elements were serious concerning as a result of its excessive presence in water sample, and both metals and their compounds are generally toxic pollutants. The main sources of these two elements are natural. For instance, normally a huge amount of $\mathrm{Cd}$ ( around 25,000 tons per year) is released into the environment. Nearly $50 \%$ of this Cd delivered into streams through enduring of rocks and some $\mathrm{Cd}$ is released through jungle fires and volcanoes. The rest of the $\mathrm{Cd}$ is delivered through anthropogenic inputs. Cd can be transported over significant stretches when it is absorbed by sludge. This Cd-rich sludge can contaminate surface waters just as soils (Islam et al., 2020a). Furthermore, water contamination containing $\mathrm{Pb}$ compounds resulting from $\mathrm{Pb}$ minerals in the mining activities. Additionally, with mining, Pb compound "tetra-ethyl lead" is applied as an added substance in gasoline in numerous nations (Rahman et al., 2019). This natural Pb compound is immediately converted to inorganic lead, and winds up in water, in some cases even in drinking water.

\subsection{Water quality assessment of PTEs in surface water}

The Entropy Water Quality Index (EWQI) is based on the average weighted of the considered parameters that are able to determine the water quality (Singh et al., 2021). Entropy along with other relevant information delineates measurements that express a long-term behavior of random processes (Gorgij et al., 2017). When the concentration of PTEs is frequently above the drinking water standard, the water is unsafe for human consumption and agricultural usage (WHO, 2011). Site samples are linked to domestic waste, household sewage and industrial effluents, such as gold mine derived waste material, all of which are heavily polluted due to $\mathrm{Ni}, \mathrm{Cd}$, and $\mathrm{Pb}$ concentrations in the surface water. To identify the water quality for the drinking purpose, the critical limit for EWQI estimation is set at EWQI=100, implying that 100 percent of the tested samples are over the crucial value (>100). Only $12.5 \%$ of the analyzed samples are of moderate grade (EWQI: 100-150), indicating that they can be utilized for residential, irrigation, and industrial purposes rather than drinking. In the research area, $87.5 \%$ of sampling sites provide water that is of poor to extremely poor quality, making it unfit for any use. The presence of elevated levels of contaminants such as Cd, Zn and Cu in water samples may be the cause of poor water quality that might be resulted from anthropogenic inputs such as fast industrialization, urbanization, and the disposal of industrial waste materials. This study showed that the highest metal concentration was found at the sampling point of W4 followed by W8 $>$ W6 $>$ W2 $>$ W7 $>$ W1 > W5 $>$ W3, while the descending trend for entropy water quality index (EWQI) was followed as W8 $>$ W2 $>$ W4 $>$ W1 > W6 > W7 > W3 > W5 ranging from 148 to 468 (Table 3).

Kumar et al., (2021) reported that the surface water contamination was caused by the massive volume of gold mine wastes and related household products released into the Nasivi River. The EWQI results revealed the 
state of water quality concerning PTEs pollution in the river system. Due to the elevated contents of PTEs in the river water, samples from the river were defined as unfit for consumption purposes and stated the origins of elements from towns that were from anthropogenic inputs (Xiao et al., 2019). The spatial distribution map of EWQI revealed that in comparison to the rest of the locations, the northern and northwestern areas have higher EWQI values (Fig. 2). Overall, the majority of the sites with good-quality water and the study locations are located in the southern and southeastern areas. Hence, in these riverine areas with poor water quality, appropriate management strategies for de-silting and constant monitoring urgently needed (Xiao et al., 2019).

\subsection{Eco-environmental appraisals of PTEs in sediment}

Figure 3a outlined the EF values of the studied PTEs from the sediments of the Wainivesi River system in Fiji. The calculated EFs of the selective PTEs contents like $\mathrm{Cr}, \mathrm{Mn}, \mathrm{Fe}, \mathrm{Co}, \mathrm{Ni}, \mathrm{Cu}, \mathrm{Zn}, \mathrm{Cd}$, and Pb are 1.298, 1.028, $1.0,1.369,2.793,2.119,2.936,3.303$, and 1.838, respectively, presented in Table S4. We can organize the EFs of the PTEs according to their mean in the following order: $\mathrm{Cd}>\mathrm{Zn}>\mathrm{Ni}>\mathrm{Cu}>\mathrm{Pb}>\mathrm{Co}>\mathrm{Cr}>\mathrm{Mn}>\mathrm{Fe}$. Our result shows that except for $\mathrm{Cr}, \mathrm{Mn}, \mathrm{Fe}$, and $\mathrm{Co}$, the remaining PTEs had EF values greater than $1.5(1.5 \leq \mathrm{EF}<$ 3), demonstrating minor enrichment of the PTEs in sediment and implying anthropogenic origins (Ustaolu and Islam, 2020; Islam et al., 2020a). On the contrary, metals like $\mathrm{Cr}$, Mn, Fe, and Co had low EF values, implying geogenic inputs as the key factors of these toxic elements (Ustaolu and Islam, 2020; Varol and Sen 2012; Gao and Chen 2012). Wang et al. (2008) reported that EF values of 0.5 EF 1.5 indicate that the origin of the elements is purely geogenic, but an EF value of $>1.5$ indicates that the elements are from anthropogenic sources. Shirani et al., (2020) reported that dysprosium (Dy), $\mathrm{Pb}$, and $\mathrm{Ni}$ is highly enriched compared to other metals, indicating an intense anthropogenic activity in the study area which was similar to our study.

$\mathrm{I}_{\text {geo }}$ is a critical ecological index that is used to differentiate between natural and human-caused metal sources, as well as to assess the contamination level of sediment samples (Islam et al., 2020a). The analyzed $\mathrm{I}_{\text {geo }}$ values of the considered PTEs were included in supplementary Table S5 and delineated in the following descending order based on their mean (relative to the background dataset): $\mathrm{Ni}(0.748)>\mathrm{Pb}(0.138)>\mathrm{Cu}$ $(0.016)>\mathrm{Co}(-0.061)>\mathrm{Zn}(-0.077)>\mathrm{Cr}(-0.119)>\mathrm{Cd}(-0.142)>\mathrm{Fe}(-0.466)>\mathrm{Mn}(-0.533)$ (Fig. 3b). The highest $\mathrm{I}_{\text {geo }}$ value was found for $\mathrm{Cd}$ (3.801), while the lowest $\mathrm{I}_{\text {geo }}$ value was found for $\mathrm{Fe}(-2.455)$. Cd and $\mathrm{Zn}$ were observed as "strongly contaminated" in sampling sites 1 and 2 while Cu was observed as "moderately to heavily contaminated" in sampling sites 1 and 2 while Ni was investigated as "moderately contaminated" in some sites 4, 6, 7 and 8. To compare with other studies, Song et al. (2019) observed similar findings in China's Zhauyuan city goldmine. The river sediments were regarded as contaminated with $\mathrm{Cd}, \mathrm{Pb}, \mathrm{Zn}$, and Ni, which already exceed the acceptable levels considering the background values in an earlier section (Table 2). Moreover, the $I_{\text {geo }}$ values for the majority of the PTEs indicated that the studied locations were moderately to severely contaminate. Previous studies from Souza et al., (2017) and (Huang et al., 2020) found a significant content of PTEs in sediments and tailing dams in gold mining and processing regions which was consistent with our findings. According to Müller (1981), the sediments of the Wainivesi River system was unpolluted to moderately polluted $\left(0<I_{\text {geo }}<1\right)$ for all PTEs.

The analyzed contamination factor (CF) values for the PTEs were depicted in Fig. 3. The average CF values for all metals were organized in the following order: $\mathrm{Cd}$ (4.628: significant contamination) $>\mathrm{Zn}$ (4.065: significant contamination) > Ni (3.149: significant contamination) > Cu (2.734: moderate contamination) > Pb (2.201: 
moderate contamination $)>\mathrm{Cr}(1.558$ : moderate contamination $)>\mathrm{Co}(1.525$ : moderate contamination $)>\mathrm{Fe}$ (1.287: moderate contamination) > Mn (1.209: moderate contamination) (Fig. 3c). In most sites, the CF values for $\mathrm{Cd}$ and $\mathrm{Zn}$ were $>2.5$, indicating a high degree of contamination, while the $\mathrm{CF}$ values for other PTEs were 1 $\leq \mathrm{CF}<3$, indicating a moderate level of contamination at all sites. The CF values for the examined PTEs at all sites showed a moderate to a high level of contamination, which could be attributed to the Wainivesi River system in Fiji absorbing a substantial volume of municipal, residential, and gold mine effluent. A significant level of Cd was observed a few sites such as sites 1 and $3(>10.0)$, indicating a high level of contamination which could be attributed to the station receiving a large amount of municipal, agricultural, household, and factory effluent (Fu et al. 2009). Moreover, Cd could be attributed to the study area from the existence of alarge-scale gold mine and wastewater drainage in the vicinity. Islam et al. (2015a, b) conducted a similar investigation in a developing country's urban river and reported that the $\mathrm{CF}$ value of $\mathrm{Pb}$ in sediment samples was 4.3 and 3.7 during the winter and monsoon seasons, respectively. Domestic wastewater drainage, industrial effluents such as mine effluents, and atmospheric deposition are the main sources of the higher level of $\mathrm{Pb}$ in the sediment. However, our CF records were higher than that of Hossain et al., (2021) who reported that Halda river sediment remained in uncontaminated condition except for $\mathrm{Pb}$.

Figure 4a summarizes the derived pollution load index (PLI) values of PTEs in sediments. The PLI value is greater than one, then the investigated region can be considered to be contaminated (Tomlinson et al. 1980) (Table S2). The PLI values for all sampling sites in the study site varied from 1.00 to 2.46 , indicating that the sediment in the study river had a high level of pollution (PLI > 1). PLI values estimated from the six PTEs ranged from 0.8 to 3.9 , with a mean of 1.95. PLI values for all sampling locations were calculated and displayed in Figure 4a to comprehend the actual distributions of the integrated PTEs loads to assess the sequential contamination status. The PLI can provide some insights into the sediment quality to the general public. It also provides crucial information to policy-makers on the state of pollution in the study region (Suresh et al., 2012).

The findings of the ecological risk index (RI) are displayed in Table S7. The value of $\mathrm{RI}$ in sediments according to descending order of $\mathrm{Cd}>\mathrm{Ni}>\mathrm{Cu}>\mathrm{Pb}>\mathrm{Zn}>\mathrm{Cr}>\mathrm{Co}>\mathrm{Mn}$ and the RI for sole PTE was observed in the low to very high-risk category. Cadmium (18.35-627.22) was noticed as the highest and noteworthy PTE in all sites and the risk factors of it was low to very high risk category for the aquatic environment, where the remaining PTEs were observed a considerable risk for the aquatic environment. After integrating the RI of each PTE (Fig. 4b) with its ranking category, it is observed that the analyzed PTE revealed considerable to very high risk group. In general, the major sources of $\mathrm{Cd}$ and $\mathrm{Ni}$ in surface sediment are the intense uses of phosphate fertilizers to the agro-farming site beside the river basin and waste disposal material from the rural area (ATSDR 2008). The RI values were 40.9 to 733.8 , which show moderate to very high ecological risk in the sampling sites, (Fig. 4b).

Similar to the PLI and RI, $\mathrm{C}_{\mathrm{d}}$ and $\mathrm{mC}_{\mathrm{d}}$ exhibited similar spatial patterns (Figs. $4 \mathrm{c}$ and d) in the studied sites. The higher amount of $C_{d}$ was noticed at sites 1 and $2(>40.00)$ indicated a very extreme degree of contamination which might be due to receiving the enormous amount of rural waste, agro-farming practices, and mine-derived wastewater at these sites (Fu et al. 2009) (Table S6). 
$\mathrm{C}_{\mathrm{d}}$ values ranged from 8.0 (7.1) to 62.4 (2.1) with a mean value of 22.36, which suggested that the Wainivesi river basin possess considerable to high level of contamiantion in the northwestern site (Fig. 4c). In contrast, values $\mathrm{mC}_{\mathrm{d}}$ varied from $0.9(7.1)$ to 6.9 (2.1) with a mean value of $2.48(\mathrm{n}=24)$, which impliyed that the tested river system were slightly to moderate heavily contaminated in mostly norwestern part near the gold mine where $\mathrm{Cd}, \mathrm{Zn}$ and Ni were the key contributors (4d).

\subsection{Quantifying source apportionment of water and sediment}

In this research, to quantify plausible sources of PTEs in the surface water and sediment from the Wainivesi River, Fiji, hierarchical cluster heat map (HCHM) and principal component analysis (PCA) were performed in Fig. 5. To confirm the appropriateness of the dataset for PCA, the Kaiser-Meyer-Olkin (KMO) and Bartlett's sphericity (BS) tests were validated before performing PCA. The KMO test score was 0.69 and 0.73 for water and sediment samples and the confidence level of BS test at $p<0.05$, indicating the both dataset in this study was appropriate for PCA. For water sample dataset, three PCAs which elucidated $89.75 \%$ of the total variance were attained via PCA (Table S8 and Fig. 5a). The first component (PC1) responsible for $54.22 \%$ of the variance and had weak positive loading on $\mathrm{Zn}(0.41)$, and $\mathrm{Mn}(0.43)$ while weak negative loading on $\mathrm{Cr}(-0.41)$ and $\mathrm{Co}$ (-0.40). Zn showed noteworthy spatial variation, while Mn did not show noteworthy spatial changes and the highest contents of Zn was found at W-1 due to the lithogenic origin and wastewater release from mine effluent from gold mining activities. Results showed that $\mathrm{Co}$ and $\mathrm{Cr}$ may be derived from geogenic contents (Guan et al., 2018). The runoff from the hilly region may be a plausible transport way of these contaminants into river water. Zn and Mn concentrations are mostly driven by geogenic sources. Hence, PC1 was contributed to natural sources.

The second component (PC2) explained for 25.52\% of the variance and had moderate positive loadings on Fe (0.64) and Cd (0.55) (Table S8). In majority of water samples, contents of Fe and Cd were five times and four times greater than the WHO standard limit values. Fe is among the most abundant elements in Earth's crust, thus may be derived from weathering of the rock-water interaction (Bodrud-Doza et al., 2016). The mean concentrations of $\mathrm{Fe}$, and $\mathrm{Cd}$ exhibited significant variations among the sampling sites, implying that there can be both mixed sources (geogenic and anthropogenic) for these PTEs along the river to change their spatial patterns. Indeed, the highest concentrations of Fe were recorded at site W4 due to both geogenic and anthropogenic sources such as mine wastes discharge and farming activities. The recorded Cd at site W1 was due to atmospheric deposition and electroplating effects (Islam et al., 2015). Long-term use of Cd as a component in fungicides and algaecides (Bodrud-Doza et al. 2016) has also been observed to be beneficial to agro-farming field. Mining industry, for example, generate and discharge wastages containing high levels of $\mathrm{Cd}$ in the effluent (Islam et al. 2015). Fe and Cd are controlled by both geogenic sources and anthropogenic inputs. Hence, the PC2 was attributable to diverse sources.

The third component (PC3) accounted for $9.99 \%$ of the variance had strong positive loadings on $\mathrm{Ni}(0.73)$ and weak negative loadings on $\mathrm{Pb}(-.36)$ and $\mathrm{Cu}(-0.38)$ (Table S8). Ni, and $\mathrm{Cu}$ derived from anthropogenic inputs, especially, waste, and agro-farming fields (Cheng et al., 2020; Islam et al., 2020a). Ni and Pb concentrations were two times and nineteen times higher than the guideline values for threatening aquatic organisms and for drinking water purpose (Table 3). Motor exhaust contributes a significant amount of $\mathrm{Pb}$ to the water body, in addition to oil leakage from boats and steamers (Namngam et al., 2021). These findings indicated that these

Page 26/46 
PTEs are mainly controlled by anthropogenic processes. Hence, PC3 was attributable to anthropogenic sources. Overall, the PCA showed two main sources of PTEs contamination in the aquatic environment were human-induced and geogenic contents.

For sediment sample dataset, three PCAs which explained $93.96 \%$ of the total variance were attained via PCA (Table S8 and Fig. 5b). The first component (PC1) responsible for $55.20 \%$ of the variance and had weak positive loading on $\mathrm{Mn}(0.40), \mathrm{Cu}(0.40), \mathrm{Zn}(0.39), \mathrm{Cd}(0.38)$ and $\mathrm{Pb}(0.42)$. In most of sampling sites, $\mathrm{Zn}, \mathrm{Pn}$ and $\mathrm{Cd}$ were about fifteen times, five times and thirty-four times higher than their guideline values. Fertilizers, electroplating, $\mathrm{Cd}$ containing alloys, foils, oils, and other applications use $\mathrm{Cd}$ that deposited into riverbed sediment (Namngam et al., 2021). Pb can come into the river sediments from urban waste leach out comprising Ni-Cd batteries from automobile factories, batteries, and smelting electroplants (Fang et al. 2019). Earlier cited work revealed that $\mathrm{Pb}$ and $\mathrm{Zn}$ in the riverine basin were likely attributed to release from industrial sewages and wastes (Islam et al., 2020a; Namngam et al., 2021). Currently, this is occurring daily at the study site near the gold mine as a dumpling sites for their wastewater materials. This finding is in line with sediment pollution in other regions of the world (Emenike et al., 2020). On the other hand, the sources of $\mathrm{Mn}$ and $\mathrm{Cu}$ could be related with lithogenic inputs including soil erosion than enhances during the wet period due to the surficial run-off (Islam et al., 2020b). Mn may be discharged into the water via biogeochemical process of pyroclastic sediment (Ahmed et al., 2019). Hence, PC1 was contributed to mixed sources.

The second component (PC2) explained for 31.25\% of the variance and had moderate loadings on Co (0.51), $\mathrm{Cr}(0.48)$ and $\mathrm{Ni}(0.50)$ (Table S8). In sediment samples, their mean contents were lower than the standard values for protecting aquatic lives (Table 3 ). This finding suggested that these PTEs are mainly controlled by geogenic processes viz. municipal and mine waste releases (Emenike et al., 2020; Hence, this component was contributed to geogenic sources.

The third component (PC3) accounted for $7.51 \%$ of the variance had strong negative loading on Fe $(-0.75)$ and weak positive loadings on $\mathrm{Co}(0.43)$ and $\mathrm{Pb}(0.39)$ (Table S8). Fe is related to a likely blend of organic matter overlapped on geogenic content (Emenike et al., 2020). Co may be originated from geogenic sources (Guan et al., 2018). In this study, Pb showed significant spatial variation and Co did not show noteworthy spatial changes. The mean content of $\mathrm{Pb}$ was about five times greater than guideline value. This was due to substantial anthropogenic inputs. Furthermore, the 90th percentile contents of $\mathrm{Cu}$ and $\mathrm{Pb}$ were below the standard limit values for safeguard of freshwater aquatic system and for consumption purpose (Table S8). Pb has a long history of use as an anti-corrosive element in steels and gold industry, as well as an anti-knocking ingredient in gasoline and diesel fuels (Emenike et al. 2020). These outcomes showed that Fe, and Co concentrations are influenced by geogenic source while $\mathrm{Pb}$ is driven by substantial anthropogenic sources. Thus, this last component was contributed to mixed sources. Overall, the PCA results suggested two major sources of PTEs contamination in the sediment.

The two-way hierarchical cluster heat map ( $\mathrm{HCHM})$ and dendrogram were generated in this research using the Ward linkage technique with Euclidean distance, and the outcomes are displayed in Fig. 6. The HCHM is often applied to verify the PCA findings. In this research, for water samples, the HCHM grouped the 9 PTEs into three clusters (Fig. 6a) in the vertical portion. The first (Pb, Fe, $\mathrm{Cr}$ and $\mathrm{Ni}$ ) containing Sites 1, and 2 and second clusters (Co, Mn, Cd and $\mathrm{Cu}$ ) consisting of sites 3, 5, 6 and 7 could be ascribed to the mixed sources of both 
geogenic and human-induced sources. The third (Zn) cluster represented sites 4 and 8 indicate anthropogenic sources. Thus, the HCA results were in good agreement with the PCA outcomes.

For sediment samples, in the vertical portion, the dendrogram presented two clusters: cluster 1 was limited to Fe and $\mathrm{Cu}$ which consisted of sites 1, and 2 indicating geogenic source, while cluster two represent $\mathrm{Cr}, \mathrm{Zn}, \mathrm{Cd}$, $\mathrm{Co}, \mathrm{Pb}, \mathrm{Ni}$ and $\mathrm{Mn}$ contained the remaining sites, indicating intense anthropogenic sources (Fig. 6b). Such findings verified a comparable source of the selected PTEs in PCA results.

\subsection{Spatial pattern of PTEs in water and sediment using SOM analysis}

The component planes of SOM outcomes were outlined in Fig. 7. SOM planes were developed in color codes for exhibiting the significance of specific variables for each SOM class. The smaller the space of hexagon is, the more analogous the features of samples are. In the planes, a similar color revealed a positive association between variables, while different colors implied negative associations. For water dataset, each parameter resembled as illustrated in Fig. 7a. In the planes, three spatial patterns are evident to the surface water. First, $\mathrm{Zn}$, and $\mathrm{Mn}$ exhibited likely patterns to $\mathrm{Co}$ and $\mathrm{Cr}$; their weight values enhanced from the lower to the upper sides. Second, contrasting other PTEs contents, $\mathrm{Cd}$ and Fe revealed horizontal gradient (elevated from the left to right side) in color patterns, indicating that both PTEs are controlled by mixed procedures from those affecting the main elements. Third, $\mathrm{Ni}$ and $\mathrm{Pb}$ values revealed more complicated color patterns than other elements with rising from the lower left to the upper right sides (Fig. 7a) which may be due to the impact from untreated waste material from rural area and gold mine-induced effluents, atmospheric precipitation, and roadside dust particle (Islam et al., 2015a; 2020a). Cu was similar to Zn and elevated concentrated at the lower left corner which might be due to high agro-chemical fertilizer usage linkage with vegetable besides the river system (Dash et al., 2020). Interestingly, the pollution sources of PTEs in surface water from the SOM analysis showed an analogous pattern of PTEs distribution in the clusters and PCA in this research.

For surface sediment samples, three spatial patterns are obvious in the planes (Fig. 7b). First, Zn, and Cd depicted similar patterns to $\mathrm{Cu}$ and $\mathrm{Mn}$; their weight values enhanced toward the left to the right corners. These PTEs indicated a common association among the elements. Second, analogous to these PTEs, Cr and $\mathrm{Ni}$ are also alike color patterns and the extremely distributed on the lower left corner. These toxic elements are derived from human-induced inputs, particularly, waste and extensive agro-farming production (Islam et al., 2020a). Third, $\mathrm{Fe}, \mathrm{Co}$ and $\mathrm{Pb}$ depicted complex color distributions than other PTEs, indicating extensive human-induced and geogenic inputs are liable for governing the sediment quality in the river basin. Such findings of SOM analysis also verified a comparable source of the selected PTEs in PCA outcomes in earlier section.

\section{Conclusion}

This is the first inclusive study to investigate contamination levels of PTEs in surface water and sediment of Wainvesi River, Fiji induced by gold-mining activities. The results revealed that the contents of $\mathrm{Cd}, \mathrm{Pb}$, and $\mathrm{Ni}$ for water, and $\mathrm{Zn}, \mathrm{Pb}, \mathrm{Cd}$ and Fe for sediment were exceeded the standard limits, which implied that the Wainivesi River is severely polluted by PTEs and may pose an adverse impact on this aquatic environment. The results of EWQI revealed that $87.5 \%$ of surface water poses poor to extremely low water qualities, 
especially in most of the sample sites. The indexical approaches such as $I_{\text {geo, }} \mathrm{EF}, \mathrm{PLI}$ and CF confirmed that the sediments were heavily contaminated by PTEs at various degrees; however, diverse spatial changes were noticed for $\mathrm{Cd}$ and $\mathrm{Zn}$. The results of the potential RI showed that the highest level of ecological risk was observed in the designated area due to $\mathrm{Cd}$ and $\mathrm{Ni}$ contents. Thus, the $\mathrm{RI}$ evaluation revealed that $\mathrm{Cd}$ exhibited a substantial ecological risk, particularly the northern most and northwestern parts of the river basin area. However, a serious condition was noticed which was served at sample sites 2,3 , and 4 in which the $\mathrm{mC}_{d}$ and $\mathrm{C}_{\mathrm{d}}$ posed by $\mathrm{Cd}$ and $\mathrm{Zn}$ were exceeded the international laws.

The SOM analysis identified three spatial patterns e.g., Cr-Co-Zn-Mn, Fe-Cd and Ni-Pb-Cu in water and also three spatial patterns e.g., $\mathrm{Zn}-\mathrm{Cd}-\mathrm{Cu}-\mathrm{Mn}, \mathrm{Cr}-\mathrm{Ni}$ and $\mathrm{Fe}, \mathrm{Co}-\mathrm{Pb}$ in surface sediment indicating that these spatial patterns were able to delineate the pollution by distinctive classes of low to high pollution degrees.

Interestingly, it is observed that the result attained from the SOM evaluation in the present study were consistent with the findings from PCA and HCA. Thus, the integrated tools with the use of GIS-based spatial patterns were robust and important for the source apportionment of PTEs in the analyzed samples. The results of PCA analysis depicted two types of sources in sediment (e.g., geogenic and point sources) and similarly, two types of sources in water (e.g., lithogenic and human-induced inputs) as the reasons for water resource pollution. In summary, source identification of PTEs and zonation of eco-environmental logical risk attained from the present research will be helpful for decision makers to articulate sustainable-based pollution control measures for the gold-mining activities.

\section{Declarations}

\section{Acknowledgement}

We acknowledge to the Lorenzo Savea, Kemueli Naiqama, Elizabeth Pua, Chris Kao and Esther Talei for their assistant in collecting and arranging the sample preparation for our research work.

\section{Funding}

The authors extend their appreciation to the Deanship of Scientific Research at King Khalid University for funding this work through the Research Group Project under grant number [R.G.P.2/33/42].

\section{Ethical approval}

Not applicable

\section{Consent to Participate}

Not applicable

\section{Consent to Publish}

Not applicable

\section{Data availability}


Data are available upon request on the corresponding author

\section{Code availability}

Not applicable

\section{Author contributions}

A.R.M.T., S.K., and M. H., designed, planned, conceptualized, drafted the original manuscript, and R.K., and M.S.I., was involved in statistical analysis, interpretation; A.R.M.T.I., R.S., and M.M.A., contributed instrumental setup, data analysis, validation; A.E., M.S.R., S.C.P., and M.H., contributed to editing the manuscript, literature review, proofreading; W.G., M.S.R., A.M.I, and A.R.M. T.I., were involved in software, mapping, and proofreading during the manuscript drafting stage.

\section{Conflict of interest}

The authors declare that they have no conflict of interest.

\section{References}

1. Abdul-Wahab, S.; Marikar, F. (2012). The environmental impact of gold mines: Pollution by heavy metals. Open Eng., 2, 304-313.

2. Aboud, J.S., Nandini, N., 2009. Impact assessment of heavy metals pollution of Vartur lake, Bangalore. J. Appl. Nat. Sci. 1, 53e61.

3. Abrahim, G. M. S., \& Parker, R. J. (2007). Assessment of heavy metal enrichment factors and the degree of contamination in marine sediments from Tamaki Estuary, Auckland, New Zealand. Environmental Monitoring and Assessment, 136(1-3), 227-238. https://doi.org/10.1007/s10661-007-9678-2

4. Ackley, M., 2008. Evaluating Environmental Risks in Mining: a Perceptual Study at the Vatukoula Goldmine in Fiji. MSc Thesis. The University of Vermont, USA.

5. Adewumi, A.J., Laniyan, T.A., 2020. Contamination, sources and risk assessments of metals in media from Anka artisanal gold mining area, Northwest Nigeria. Sci. Total Environ. 137235.

6. Ahmed, F.T., Khan, A.H.A.N., Khan, R., Saha, S.K., Alam, F.A., Dafader, N.C., Sultana, S., Elius, I.B., Mamun, S.A., 2021. Characterization of Arsenic contaminated groundwater from central Bangladesh: Irrigation feasibility and preliminary health risks assessment. Environmental Nanotechnology, Monitoring and Management, 14, (https://doi.org/10.1016/j.enmm.2021.100433)

7. Ahsan, M.A., Satter, F., Siddique, M.A.B., Akbor, M.A., Shamim, A., Shajahan, M., Khan, R., 2019. Chemical and physicochemical characterization of effluents from the tanning and textile industries in Bangladesh with multivariate statistical approach. Environ Monit Assess, (https://doi.org/10.1007/s10661-019-76542)

8. Ali, M.M., Ali, M.L., Islam, M.S., Rahman, M.Z., 2018. Assessment of toxic metals in water and sediment of Pasur River in Bangladesh. Water Sci. Technol. 77 (5), 1418-1430. https://doi.org/10.2166/wst.2018.016.

9. Ali, M.M., et al., 2016. Preliminary assessment of heavy metals in water and sediment of Karnaphuli River, Bangladesh. Environmental nanotechnology monitoring and management, 5, 27-35. 
10. Alizadeh, M.J., Nodoushan, E.J., Kalarestaghi, N., Chau, K.W., 2017. Toward multi-dayahead forecasting of suspended sediment concentration using ensemble models. Environ. Sci. Pollut. Res. 24, 28017-28025.

11. Atibu, E. K., Devarajan, N., Laffite, A., Giuliani, G., Salumu, J. A., Muteb, R. C., Mulaji, C. K., Otamonga, J.-P., Elongo, V., Mpiana, P. T., \& Poté, J. (2016). Assessment of trace metal and rare earth elements contamination in rivers around abandoned and active mine areas. The case of Lubumbashi River and Tshamilemba Canal, Katanga, Democratic Republic of the Congo. Geochemistry, 76(3), 353-362. https://doi.org/10.1016/j.chemer.2016.08.004

12. Bempah, C.K., Ewusi, A.; Obiri-Yeboah, S., Asabere, S.B.; Mensah, F., Boateng, J., Voigt, H.-J. (2013). Distribution of arsenic and heavy metals from mine tailings dams at Obuasi municipality of Ghana. Am. J. Eng. Res., 2, 61-70.

13. Bhuiyan, M.A.H., Dampare, S.B., Islam, M.A., Suzuki, S., 2015. Source apportionment and pollution evaluation of heavy metals in water and sediments of Buriganga River, Bangladesh, using multivariate analysis and pollution evaluation indices. Environ. Monit. Assess. 187, 4075.

https://doi.org/10.1007/s10661-014-4075-0

14. Bhuyan, M. S., Bakar, M. A., Akhtar, A., Hossain, M. B., Ali, M. M., \& Islam, M. S. (2017). Heavy metal contamination in surface water and sediment of the Meghna River, Bangladesh. Environmental nanotechnology, monitoring \& management, 8, 273-279.

15. Bitala, M.F., Kweyunga, C., Manoko, M.L. (2009). Levels of Heavy Metals and Cyanide in Soil, Sediment and Water fromthe Vicinity of North Mara Gold Mine in Tarime District, Tanzania; Christian Council of Tanzania: Dodoma, Tanzania.

16. Bodrud-Doza, M., Islam, A.R.M.T., Ahmed, F., Das, S., Saha, N., Rahman, M.S., 2016. Characterization of groundwater quality using water evaluation indices, multivariate statistics and geostatistics in central Bangladesh.Water Science 30,19e40. https://doi.org/10.1016/j.wsj

17. Brügmann, L. (1995) Metals in sediments and suspended matterof the river Elbe. Sci Total Environ 159 : $\underline{53-65}$

18. Céréghino, R., Park, Y.S., 2009. Review of the Self-Organizing Map (SOM) approach in water resources: Commentary. Environmental Modelling and Software 24, 945-947. https://doi.org/10.1016/j.envsoft.2009.01.008.

19. Cheng, W., Le, S., Bian, Z., Zhao, Y., Li, Y., Gan, Y., 2020. Geographic distribution of heavy metals and identification of their sources in soils near large, open-pit coal mines using positive matrix factorization. J. Hazard Mater. 387, 121666. https://doi.org/10.1016/j.jhazmat.2019.121666

20. Dash, S., Borah, S.S., Kalamdhad, A.S. 2020. Application of positive matrix factorization receptor model and elemental analysis for the assessment of sediment contamination and their source apportionment of Deepor Beel, Assam, India Ecol. Indic., 114, 10629. https://doi.org/10.1016/j.ecolind.2020.106291

21. Diarra, I., Prasad, S., 2020. The current state of heavy metal pollution in Pacific Island Countries: a review,. Appl. Spectrosc. Rev. 1-23. https://doi.org/10.1080/ 05704928.2020.1719130, 0:0.

22. Dragun, Z., Roje, V., Mikac, N., Raspor, B., 2009. Preliminary assessment of total dissolved trace metal concentrations in Sava River water. Environ. Monit. Assess. 159, 99e110

23. ECR (The Environment Conservation Rules), 1997. Government of the People's Republic of Bangladesh, Ministry of Environment and Forest. 
24. Elias, M.S., Ibrahim, S., Samuding, K., Rahman, S.A., Wo, Y.M., Daung J.A.D. (2018) Multivariate analysis for source identification of pollution in sediment of Linggi River, Malaysia Environ. Monit. Assess., 190,.p. 257, 10.1007/s10661-018-6632-4

25. Emenike, P. C., Tenebe, I. T., Neris, J. B., Omole, D. O., Afolayan, O., Okeke, C. U., \& Emenike, I. K. 2020. An integrated assessment of land-use change impact, seasonal variation of pollution indices and human health risk of selected toxic elements in sediments of River Atuwara, Nigeria. Environmental Pollution, 265, 114795. https://doi.org/10.1016/j.envpol.2020.114795

26. Eneji, I.S., Rufus, S., Annune, P.A., 2012. An assessment of heavy metals loading in river Benue in the makurdi metropolitan area in Central Nigeria. Environ. Monit. Assess. 184, 201e207.

27. EPA (Environmental Protection Agency). 2001. Parameters of water quality. Interpretation and Standards. Published by the Environmental Protection Agency, Ireland.

28. EU (European Commission), 1998. Council Directive 98/83/EC on the quality of water intended for human consumption.

29. Fashola, M.O., Ngole-Jeme, V.M., Babalola, O.O. (2016). Heavy Metal Pollution from Gold Mines:

Environmental Effects and Bacterial Strategies for Resistance. Int. J. Environ. Res. Public Health 13: 1047.

30. Fu J, Zhao C, Luo Y, Liu C, Kyzas GZ, Luo Y, Zhao D, An S, Zhu H., 2014. Heavy metals in surface sediments of the Jialu River, China: their relations to environmental factors. J Hazard Mater 270:102-109

31. Gao, Q., Li, Y., Cheng, Q., Yu, M., Hu, B., Wang, Z., Yu, Z., 2016. Analysis and assessment of the nutrients, biochemical indexes and heavy metals in the three gorges reservoir, China, from 2008 to 2013. Water Res. 92, 262-274. http://dx.doi.org/10.1016/j.watres.2015.12.055.

32. Garzanti, E., Andò, S., France-Lanord, C., Vezzoli, G., Censi, P., Galy, V., \& Najman, Y. (2010). Mineralogical and chemical variability of fluvial sediments. Earth and Planetary Science Letters - EARTH PLANET SCI LETT, 299, 368-381.

33. Giri, S., Singh, A.K., 2014. Risk assessment, statistical source identification and seasonal fluctuation of dissolved metals in the Subarnarekha River, India. J. Hazard Mater. 265, 305e314

34. Gorgij, A. D., Kisi, O., Moghaddam, A. A., \& Taghipour, A. (2017). Groundwater quality ranking for drinking purposes, using the entropy method and the spatial autocorrelation index. Environmental earth sciences, 76(7), 269.

35. Grimalt, J.O., Ferres, M., and Macpherson, E. 1999. The mine tailing accident in Aznalcolla. Sci. Tot. Environ. 242, 3-11.

36. Guan, Q., Wang, F., Xu, C., Pan, N., Lin, J., Zhao, R., Yang, Y., Luo, H., 2018. Source apportionment of heavy metals in agricultural soil based on PMF: a case study in Hexi Corridor, northwest China. Chemosphere 193, 189e197. https://doi.org/10.1016/j.chemosphere.2017.10.151

37. Hadzi, G.Y., Essumang, D.K., Ayoko, G.A., 2018. Assessment of contamination and health risk of heavy metals in selected water bodies around gold mining areas in Ghana. Environ. Monit. Assess. 190 (7).

38. Hakanson, L. (1980). Ecological risk index for aquatic pollution control, a sedimetological approach. Wa t e r Research, 14, 975-1001. http://dx.doi.org/10.1016/0043-1354(80): 90143-8

39. Hasan, M.N., Siddique, M.A.B., Reza, A.H.M.S., Khan, R., Akbor, M.A., Elius, I.B., Hasan, A.B., Hasan, M., 2021. Vulnerability assessment of seawater intrusion in coastal aquifers of southern Bangladesh: Water 
quality appraisals. Environmental Nanotechnology, Monitoring \& Management, 16, 100498.

(https://doi.org/10.1016/j.enmm.2021.100498)

40. Hentati, A., Kawamura, A., Amaguchi, H., Iseri, Y., 2010. Evaluation of sedimentation vulnerability at small hillside reservoirs in the semi-arid region of Tunisia using the Self-Organizing Map. Geomorphology. 122, 56-64. https://doi.org/10.1016/j.geomorph.2010.05.013

41. Hornung, H, Krom, M. D. and Cohen, Y. (1989) Trace metal distribution in sediments and benthic fauna of Haifa Bay, Israel Estuat: Coastal Shell" SoL 29, 43-56

42. Hossain, M. B., Semme, S. A., Ahmed, A. S. S., Hossain, M. K., Porag, G. S., Parvin, A., ... \& Sekar, S. (2021). Contamination levels and ecological risk of heavy metals in sediments from the tidal river Halda, Bangladesh. Arabian journal of geosciences, 14(3), 1-12.

43. Hu, W. Y., Wang, H. F., Dong, L. R., Huang, B., Ole, K. B., Hans, C. B. H., He, Y., \& Peter, E. H. (2018). Source identification of heavy metals in peri-urban agricultural soils of southeast China: An integrated approach. Environmental Pollution, 237, 650-661.

44. Huang, Y.N., Fei Dang, F., Li, M., et al., 2020. Environmental and human health risks from metal exposures nearby a Pb-Zn-Ag mine, China. Sci. Total Environ. 698, 134326.

45. Islam, A.R.M.T., Ahmed, N., Bodrud-Doza, M., Chu, R., 2017. Characterizing groundwater quality ranks for drinking purposes in Sylhet district, Bangladesh, using entropy method, spatial autocorrelation index, and geostatistics. Environ. Sci. Pollut. Control Ser. 24 (34), 26350e26374. https://doi.org/10.1007/s11356017-0254-1

46. Islam, A.R.M.T., Hasanuzzaman, M., Islam, H.M.T., et al., 2020a. Quantifying source apportionment, Co-occurrence and ecotoxicological risk of metals from up-middownstream river segments, Bangladesh. Environ. Toxicol. Chem. https://doi.org/ 10.1002/etc.4814.

47. Islam, A.R.M.T., Islam, H.M.T., Mia, M.U., Khan, R., Habib, M.A., Bodrud-Doza, M., Siddique, M.A.B., Chu, R., 2020b. Co-distribution, possible origins, status and potential health risk of trace elements in surface water sources from six major river basin, Bangladesh. Chemosphere 249, 126180.

48. Islam, G.M.R., Khan, F.E., Hoque, M.M., Jolly, Y.N., 2014. Consumption of unsafe food in the adjacent area of Environ Hazaribag tannery campus and Buriganga River embankments of Bangladesh: heavy metal contamination. Environ. Monit. Assess. 186, 7233e7244. https://doi.org/10.1007/s10661-014-3923-2.

49. Islam, M.S., Ahmed, M.K., Raknuzzaman, M., Al-Mamun, M.H., Islam, M.K., 2015. Heavy metal pollution in surface water and sediment: A preliminary assessment of an urban river in a developing country. Ecological Indicators, 48: 282-291.

50. Islam, M.S., Proshad, R., and Ahmed, S., 2018. Ecological risk of heavy metals in sediment of an urban river in Bangladesh. Human and ecological risk assessment: an international journal, 24 (3), 699-720.

51. Jin, Y.H., Kawamura, A., Park, S.C., Nakagawa, N., Amaguchi, H., Olsson, J., 2011.Spatiotemporal classification of environmental monitoring data in the Yeongsan River basin, Korea, using self-organizing maps. Journal of Environmental Monitoring 13, 2886-2894. https://doi.org/10.1039/c1em10132c.

52. Jones, G. B., \& Jordan, M. B. (1979). The distribution of organic material and trace metals in sediments from the River Liffey Estuary, Dublin. Estuarine and Coastal Marine Science, 8(1), 37-47. 
https://doi.org/10.1016/0302-3524(79)90104-X

53. Kabata-Pendias, A.; Pendias, H. (2001). Trace Elements in Soils and Plants; CRC Press: Boca Raton, FL, USA.

54. Kapia, S., Rao, B.K.R., Sakulas, H., 2016. Assessment of heavy metal pollution risks in Yonki Reservoir environmental matrices affected by gold mining activity. Environ. Monit. Assess. 188 (10), 586. https://doi.org/10.1007/s10661-016-5604-9.

55. Kazi TG, Arain MB, Jamali MK, Jalbani N, Afridi HI, Sarfraz RA, Baig JA, Shah AQ (2009) Assessment of water quality of polluted lake using multivariate statistical technique: a case study. Ecotoxicol Environ Safety 72:301-309

56. Khan, R., Islam, M S., Tareq, A. R. M., Naher, K., Islam, A. R. M, T., Habib, M, A., Siddique, M, A. B., Islam, M. A., Das, S., Rashid, M, B., Ullah, A. K. M. A., Miah, M, M. H., Masrura, S. U., Bodrud-Doza, M, Sarker, M. R., \& Badruzzaman, A. B. M. (2020). Distribution, sources and ecological risk of trace elements and polycyclic aromatic hydrocarbons in sediments from a polluted urban river in central Bangladesh. Environmental Nanotechnology, Monitoring \& Management, 14, 100318. https://doi.org/10.1016/j.enmm.2020.100318

57. Khan, R., Rouf, M. A., Das, S., Tamim, U., Naher, K., Podder, J., Hossain, S. M., (2017). Spatial and multi layered assessment of heavy metals in the sand of Cox's-Bazar beach of Bangladesh. Reg. Stud. Mar. Sci., 16, 171-180. (https://doi.org/10.1016/j.rsma.2017.09.003)

58. Khan, R., Shirai, N., Ebihara, M., 2015b. Chemical Characteristics of R chondrites in the light of REE, Th, U and P abundances. Earth Planet. Sci. Lett. 422, 18-27. (https://doi.org/10.1016/j.epsl.2015.04.008)

59. Khan, R., Yokozuka, Y., Terai, S., Shirai, N., Ebihara, M., 2015a. Accurate determination of Zn in geological and cosmochemical rock samples by isotope dilution inductively coupled plasma mass spectrometry. J. Anal. At. Spectrom. 30, 506-514. (https://doi.org/10.1039/c4ja00344f)

60. Kim, Y., Kim, BK. \& Kim, K. Distribution and speciation of heavy metals and their sources in Kumho River sediment, Korea. Environ Earth Sci 60, 943-952 (2010). https://doi.org/10.1007/s12665-009-0230-2

61. Kohonen, T., 1982. Self-organized formation of topologically correct feature maps. Bio. Cybernetics 43 (1), 59-69.

62. Kohonen, T., 2001. Self-organizing maps, third ed. Springer, Berlin

63. Kormoker, T., Proshad, R., \& Islam, M. S. (2019b). Ecological risk assessment of heavy metals in sediment of the Louhajang River, Bangladesh. SF Journal of Environmental and Earth Science, 2(2), 1030.

64. Kormoker, T., Proshad, R., Islam, M.S., Ahmed, S., Chandra, K., Uddin, Rahman, M., 2019a. Toxic metals in agricultural soils near the industrial areas of Bangladesh: ecological and human health risk assessment. Toxin Rev. https://doi.org/10.1080/15569543.2019.1650777.

65. Kumar S, Islam ARMT, Islam HMT, Hasanuzzaman M, Ongoma V, Khan R, Mallick J., 2021. Water resources pollution associated with risks of heavy metals from Vatukoula Goldmine region, Fiji. Journal of Environmental Management, 293, 112868.

66. Kumar, D., Malik, D. S., Kumar, N., Gupta, N., \& Gupta, V. (2020). Spatial changes in water and heavy metal contamination in water and sediment of river Ganga in the river belt Haridwar to Kanpur. Environmental geochemistry and health, 42(7), 2059-2079. 
67. Kumara, S., Islamb, A.R.M.T., Islam, H.M.T., Hasanuzzaman, M., Ongoma, V., Khan, R., Mallick, J. (2021). Water resources pollution associated with risksof heavy metals from Vatukoula Goldmine region, Fiji. Journal of Environmental Management 293: 112868.

68. Lenard, J. G., Pietrzyk, M., \& Cser, L. (1999). Knowledge Based Modeling. In Mathematical and Physical Simulation of the Properties of Hot Rolled Products (pp. 279-318). Elsevier.

https://doi.org/10.1016/B978-008042701-0/50009-7

69. Li, S., \& Zhang, Q. (2010). Risk assessment and seasonal variations of dissolved trace elements and heavy metals in the Upper Han River, China. Journal of Hazardous Materials, 181(1-3), 1051-1058. https://doi.org/10.1016/j.jhazmat.2010.05.120

70. Li, Y., Wright, A., Liu, H., Wang, J., Wang, G., Wu, Y., Dai, L.2019. Land use pattern, irrigation, and fertilization effects of rice-wheat rotation on water quality of ponds by using self-organizing map in agricultural watersheds. Agric. Ecosyst. Environ. 272, 155-164.

https://doi.org/10.1016/j.agee.2018.11.021

71. Liu, R., Bao, K., Yao, S., Yang, F., \& Wang, X. (2018). Ecological risk assessment and distribution of potentially harmful trace elements in lake sediments of Songnen Plain, NE China. Ecotoxicology and Environmental Safety, 163, 117-124.

72. Maata, M., Singh, S. 2008. Heavy metal pollution in Suva harbour sediments, Fiji. 6(2), 113-118. https://doi.org/10.1007/s10311-007-0122-1.

73. MacDonald, D.D., Ingersoll, C.G., and Berger, T.A., 2000. Development and evaluation of consensus-based sediment quality guidelines for freshwater ecosystems. Archive environmental contamination and toxicology, 39 (1), 20-31

74. Madzin, Z., Shai-in, M.F., Kusin, F.M., 2015. Comparing heavy metal mobility in active and abandoned mining sites at bestari jaya, selangor. Procedia Environ. Sci. 30, $232 \mathrm{e} 237$.

75. Mari, M., Nadal, M., Schuhmacher, M., Domingo, J.L., 2010. Application 804 of self-organizing maps for $\mathrm{PCDD} / \mathrm{F}$ pattern recognition of environmental and biological samples to evaluate the impact of a hazardous waste incinerator. Environ. Sci. Tech. 44, 3162-3168. DOI:10.1021/es1000165

76. Maria Cavadas Morais Couto, C., Ribeiro, C., Ribeiro, A.R., Maia, A., Santos, M., Tiritan, M.E., Pinto, E., Almeida, A.A., 2019. Spatiotemporal distribution and sources of trace elements in Ave river (Portugal) lower basin: estuarine water, sediments and indigenous flora. Int. J. Environ. Res. 13, 303-318.

77. Markich, S. J., \& Brown, P. L. (1998). Relative importance of natural and anthropogenic influences on the fresh surface water chemistry of the Hawkesbury-Nepean River, south-eastern Australia. Science of The Total Environment, 217(3), 201-230. https://doi.org/10.1016/S0048-9697(98)00188-0

78. Matakarawa, S., 2018. Gold Mining and Acute Respiratory Infection in Children: A Retrospective Cohort Study in Vatukoula, Fiji. MSc Thesis. University of Canterbury, NZ.

79. Mathis, B. J., and T. F, Cummings. 1973. Selected metals in sediments, water and biota in the Illinois River. Journal Water Pollution Control Federation.45 (7) : 1573-1583.

80. Meng, Q., Zhang, J., Zhang, Z., \& Wu, T. (2016). Geochemistry of dissolved trace elements and heavy metals in the Dan River Drainage (China): Distribution, sources, and water quality assessment.

Environmental Science and Pollution Research, 23(8), 8091-8103. https://doi.org/10.1007/s11356-0166074-x

Page 35/46 
81. Mertens, J.; Degryse, F.; Springael, D.; Smolders, E. (2007). Zinc toxicity to nitrification in soil and soilless culture can be predicted with the same biotic ligand model. Environ. Sci. Technol., 41, 2992-2997.

82. Mines, D.G., 2019. Dome goldmines. Retrieved from. https://www.domegoldmines.com. au/aboutfiji/mining-in-fiji/. (Accessed 29 November 2018).

83. Mitileni, C., Gumbo, J., Muzerengi, C., Dacosta, F. (2011). The distribution of toxic metals in sediments: Case study of new union gold mine tailings, Limpopo, South Africa. In Mine Water-Managing the Challenges; IMWA: Aachen, Germany.

84. Mohiuddin, K.M., et al., 2011. Heavy metals contamination in water and sediments of an urban river in a developing country. International journal of environmental science \& technology, 8 (4), 723-736.

85. Mohiuddin, K.M., Otomo, K., Ogawa, Y., Shikazono, N., 2012. Seasonal and spatial distribution of trace elements in the water and sediments of the Tsurumi River in Japan. Environ. Monit. Assess. 184, 265279.

86. Mora, A., Jumbo-Flores, D., Gonz'alez-Merizalde, M., Bermeo-Flores, S.A., Alvarez- Figueroa, P., Mahlknecht, J., Hern'andez-Antonio, A., 2019. Heavy metal enrichment factors in fluvial sediments of an amazonian basin impacted by gold mining. Bull. Environ. Contam. Toxicol. https://doi.org/10.1007/s00128-01902545-w.

87. Muller, G. (1981). Die Schwermetallbelstung der sedimente desNeckars und seiner Nebenflusse: eine Bestandsaufnahme. Chemiker-Zeitung, 105, 156-164.

88. Namngam, N., Xue, W., Liu, X., Kootattep, T., Shrestha, R.P., Wattayakorn, G., Tabucanon, A.S., Yu, S., 2021. Sedimentary metals in developing tropical watersheds in relation to their urbanization intensities, J. Env. Manage. 278, 111521.

89. Ogola, J.S.; Mitullah, W.V.; Omulo, M.A. Impact of gold mining on the environment and human health: A case study in the Migori gold belt, Kenya. Environ. Geochem. Health 2002, 24, 141-157.

90. Palansooriya, K.N., Shaheen, S.M., Chen, S.S., Tsang, D.C.W., Hashimoto, Y., Hou, D., Bolan, N.S., Rinklebe, J., Ok, Y.S., 2020. Soil amendments for immobilization of potentially toxic elements in contaminated soils: a critical review. Environ. Int. 134.

91. Pandey LK, Park J, Son DH, Kim W, Islam, MS, Choi S, Lee H, Han T. 2019. Assessment of metal contamination in water and sediments from major rivers in South Korea from 2008 to 2015. Science of the Total Environment, 651, 323-333.

92. Park, Y.S., Céréghino, R., Compin, A., Lek, S., 2003. Applications of artificial neural net works for patterning and predicting aquatic insect species richness in running waters. Ecological Modelling 160, 265-280. https://doi.org/10.1016/S0304-3800(02)00258-2

93. Pattan, J., Parthiban, G., PrakashBabu, C., Khadge, N. H., Paropkari, A., \& Kodagali, V. N. (2008). A note on geochemistry of surface sediments from Krishna-Godavari Basin, East Coast of India. Journal of the Geological Society of India, 71.

94. Pavilonis, B., Grassman, J., Johnson, G., Diaz, Y., Caravanos, J., 2017. Characterization and risk of exposure to elements from artisanal gold mining operations in the Bolivian Andes. Environ. Res. 154, 1-9.

95. Pehlivan, R. (2010). The effect of weathering in the Buyukmelen River basin on the geochemistry of suspended and bed sediments and the hyrogeochemical characteristics of river water, Duzce, Turkey. 
Journal of Asian Earth Sciences, 39, 62-75. https://doi.org/10.1016/j.jseaes.2010.02.011

96. Pei-Yue, Li; Hui, Qian; Jian-Hua, Wu (2010). Groundwater Quality Assessment Based on Improved Water Quality Index in Pengyang County, Ningxia, Northwest China. E-Journal of Chemistry, 7(s1), S209-S216. doi:10.1155/2010/451304

97. Pereira, W.V.D.S., Renato Alves Teixeira, R.A., de Souza, E.S., et al., 2020. Chemical fractionation and bioaccessibility of potentially toxic elements in area of artisanal gold mining in the Amazon. J. Environ. Manag. 267, 110644.

98. Persuad, D., Jaagumagi, R., and Hayton, A., 1993. Guidelines for the Protection and Management of Aquatic Sediment Quality in Ontario. Ontario Ministry of the Environment, Canada

99. Rahman, M.S., Islam, M.R. (2009). Adsorption of Cd(II) ions from synthetic wastewater using Maple sawdust. Energy Sources, Part A (Recovery, Utilization and Environmental Effect) 32(3): 222-231.

100. Rahman, M.S., Kumar, S., Nasiruddin, M.., Saha, N. (2021). Deciphering the origin of $\mathrm{Cu}, \mathrm{Pb}$ and Zn contamination in school dust and soil of Dhaka, a megacity in Bangladesh. Environmental Science and Pollution Research (Accepted on March 14, 22, 2021).

101. Rahman, M.S., Saha, N., Molla, A.H. (2014). Potential ecological risk assessment of heavy metal contamination in sediment and water body around Dhaka export processing zone, Bangladesh. Environ Earth Sci., 71(5): 2293-2308.

102. Rahman, M.S.; Khan, M.D.H.; Jolly, Y.N.; Kabir, J.; Akter, S.; Salam, A. (2019). Assessing risk to human health for heavy metal contamination through street dust in the Southeast Asian Megacity: Dhaka, Bangladesh. Science of the Total Environment 660: 1610-1622.

103. Rinklebe, J., Antoniadis, V., Shaheen, S. M., Rosche, O., \& Altermann, M. (2019). Health risk assessment of potentially toxic elements in soils along the Central Elbe River, Germany. Environment International, 126, 76-88.

104. Rubio, B., Nombela, M. A., and Vilas, F., (2000). Geochemistry of major and trace elements insediments of the Ria de Vigo (NW Spain) anassessment of metal pollution, Marine PollutionBulletin, 40(11), 968-980

105. Rudnick, R. L., and Gao, S., 2003. Composition of the continental crust. In: Holland, H.D., Turekian, K.K. (Eds.), Treatisbon Geochemistry, vol. 3. Elsevier, Amsterdam, Netherlands,pp. 1-64.

106. Shannon, C. E. (1948). A Mathematical Theory of Communication. Bell System Technical Journal, 27(3), 379-423. https://doi.org/10.1002/j.1538-7305.1948.tb01338.x

107. Siegel, F.R., Slaboda, M.L., Stanley, D.J., 1994. Metal pollution loading, Manzalah Lagoon, Nile Delta, Egypt: Implications for aquaculture. Environmental Geology. 23, 89-98.

108. Shirani, M., Afzali, K. N., Jahan, S., Strezov, V., \& Soleimani-Sardo, M. (2020). Pollution and contamination assessment of heavy metals in the sediments of Jazmurian playa in southeast Iran. Scientific reports, 10(1), 1-11.

109. Siddique, M.A.B., Khan, R, Islam, A.R.M.T., Alam, M.K., Islam, M.S., Hossain, M.S., Habib, M.A., Akbor, M.A., Bithi, U.H., Rashid, M.B., Hossain, F., Rahman, I.M.M., Elius, I.B., Islam, M.S., 2021. Quality assessment of freshwaters from a coastal city of southern Bangladesh: Irrigation feasibility and preliminary health risks appraisal. Environmental Nanotechnology, Monitoring \& Management, 16, 100524.

(https://doi.org/10.1016/j.enmm.2021.100524)

Page $37 / 46$ 
110. Silva, F. B. V., Nascimento, C. W. A., Araújo, P. R. M., Silva, L. H. V., \& Silva, R. F. (2016). Assessing heavy metal sources in sugarcane Brazilian soils: an approach using multivariate analysis. Environmental Monitoring and Assessment, 188(8), 457. DOI: 10.1007/s10661-016-5409-x

111. Singh, K. R., Goswami, A. P., Kalamdhad, A. S., \& Kumar, B. (2021). Water quality evaluation and apportionment of pollution sources: a case study of the Baralia and Puthimari River (India). Water Practice \& Technology, 16(2), 692-706.

112. Song, J., Liu, Q., Sheng, Y., 2019. Distribution and risk assessment of trace metals in riverine surface sediments in gold mining area. Environ. Monit. Assess. 191 (3).

113. Song, Z., Shana, B., Tang, W., \& Zhang, C. (2017). Will heavy metals in the soils of newly submerged areas threaten the water quality of Danjiangkou Reservoir, China? Ecotoxicology and Environmental Safety, 144, $380-386$.

114. Sorokina, O.A., Zarubina, N.V. Chemical composition of the bottom sediments in the middle reaches of the Amur River. Russ. J. of Pac. Geol. 5, 469 (2011). https://doi.org/10.1134/S1819714011050095

115. Souza, E.S., Texeira, R.A., da Costa, H.S.C., et al., 2017. Assessment of risk to human health from simultaneous exposure to multiple contaminants in an artisanal gold mine in Serra Pelada, Par' a, Brazil. Sci. Total Environ. 576, 685-695.

116. Srebotnjak, T., Carr, G., de Sherbinin, A., Rickwood, C., 2012. A global water qualityindex and hot-deck imputation of missing data. Ecol. Indic. 17, 108-119.Su, S., Xiao, R., Mi, X., Xu, X., Zhang, Z., Wu, J., 2013. Spatial determinants of haz-ardous chemicals in surface water of Qiantang River, China. Ecol. Indic. 24,375-381.

117. Su, B., Heshmati, A., Geng, Y., Yu, X., 2013. A review of the circular economy in China: moving from rethoric to implementation. Journal of Cleaner Production, 42, 215-277.

118. Suresh, G., Sutharsan, P., Ramasamy, V., Venkatachalapathy, R. 2012. Assessment of spatial distribution and potential ecological risk of the heavy metals in relation to granulometric contents of Veeranam lake sediments, India Ecotoxicol. Environ. Saf., 84. pp. 117-124

119. Tamim, U., Khan R., Jolly, Y.N., Fatema, K., Das, S., Naher, K., Islam, M.A., Islam, S.M.A., Hossain, S.M., 2016. Elemental distribution of metals in urban river sediments near an industrial effluent source. Chemospher 155, 509-518. (https://doi.org/10.1016/j.chemosphere.2016.04.099).

120. Tepanosyan, G., Sahakyan, L., Maghakyan, N., Saghatelyan, A. 2021. Identification of spatial patterns, geochemical associations and assessment of origin-specific health risk of potentially toxic elements in soils of Armavir region, Armenia. Chemosphere, 262, 128365.

https://doi.org/10.1016/j.chemosphere.2020.128365

121. Tepe, Y., Türkmen, A., Türkmen, M., 2017. Comparison of heavy metal accumulation in tissues of economically valuable fish species from two nearby lagoons in Mediterranean coastal area. Indian J. GeoMarine Sci. 46, 1333-1338.

122. Thuong, N.T., Yoneda, M., Ikegami, M., Takakura, M., 2013. Source discrimination of heavy metals in sediment and water of to Lich River in Hanoi City using multivariate statistical approaches. Environ. Monit. Assess. 185, 8065e8075.

123. Tokatlı, C., Çiçek, A., Köse, E., Arslan, N., Emiroğlu, Ö., Uysal, K., 2015. Heavy metal accumulations in water, sediment, and some cyprinid species in Porsuk stream (Turkey). Water Environ. Res. 87, 195-204. 
124. Tomlinson, D.C., Wilson, J.G., Harris, C.R., Jeffrey, D.W., 1980. Problems in the assessment of heavy-metal levels in estuaries and the formation of a pollution index. Helgol. Mar. Res. 33, 566-575.

125. Turekian, K. K., \& Wedepohl, K. H. (1961). Distribution of the Elements in Some Major Units of the Earth's Crust. Geological Society of America Bulletin, 72(2), 175. https://doi.org/10.1130/00167606(1961)72[175:DOTEIS]2.0.C0;2

126. Türkmen, M., Türkmen, A., Tepe, Y., 2011. Comparison of metals in tissues of fish from Paradeniz Lagoon in the coastal area of Northern East Mediterranean. Bull. Environ. Contam. Toxicol. 87, 381-405.

127. USEPA (2001). United States Environmental Protection Agency. Update of Ambient Water Quality Criteria for Cadmium; Environmental Protection Agency: Washington, DC, USA.

128. USEPA 1999. Screening Level Ecological Risks Assessment Protocol for Hazardous Waste Combustion Facilities. Appendix E: Toxicity Reference Values. EPA 530-D99-001C, vol.3. Available from: http://www.epa.gov/epaoswer/hazwaste/combust/eco-risk/voume3/appx-e.pdf.

129. Ustaoğlua F, Islam MS. 2020. Potential toxic elements in sediment of some rivers at Giresun, Northeast Turkey: A preliminary assessment for ecotoxicological status and health risk. Ecol. Indic. 113: 106237

130. Varol, M., S, en, B., 2012. Assessment of nutrient and heavy metal contamination in surface water and sediments of the upper Tigris River, Turkey. Catena 92, 1e10

131. Varol, M., Sen, B., 2012. Assessment of nutrient and heavy metal contamination in surface water and sediments of the upper Tigris River, Turkey. Catena 92, 1-10

132. Vesanto, J., Alhoniemi, E., 2000. Clustering of the self-organizing map. IEEE Transactions on Neural Networks 11 (3), 586-600. DOI: 10.1109/72.846731

133. Vesanto, J., et al. (2000) SOM Toolbox for Matlab 5. Report A57, 60

134. Wang, J., Liu, G.J., Liu, H.Q., Lam, P.K.S., 2017. Multivariate statistical evaluation of dissolved trace elements and a water quality assessment in the middle reaches of Huaihe River, Anhui, China. Sci. Total Environ. 583, 421e431.

135. Wang, L., Guo, Z., Xiao, X., Chen, T., Liao, X., Song, J., Wu, B., 2008. Heavy metal pollution of soils and vegetables in the midstream and downstream of the Xiangjiang River, Hunan Province. J. Geogr. Sci. 18, 353-362.

136. Wang, Z., Xiao, J., Wang, L., Liang, T., Guo, Q., Guan, Y., Rinklebe, J., 2020. Elucidating the differentiation of soil heavy metals under different land uses with geographically weighted regression and self-organizing map. Environ. Pollut. 260, 114065. https://doi.org/10.1016/j.envpol.2020.114065

137. Wehrens, R. (2009). Data Mapping: Linear Methods versus Nonlinear Techniques. In Comprehensive.

138. WHO, 2011. Guidelines for Drinking-Water Quality, fourth ed. World Health Organization, Geneva, Switzerland.

139. Xiao, J., Jin, Z.D., Wang, J., 2014. Geochemistry of trace elements and water quality assessment of natural water within the Tarim River Basin in the extreme arid region, NW China. J. Geochem. Explor. 136, $118 \mathrm{e} 126$.

140. Xiao, Q., Zong, Y., Malik, Z., \& Lu, S. (2019). Source identification and risk assessment of heavy metals in road dust of steel industrial city (Anshan), Liaoning, Northeast China. Human and Ecological Risk 
Assessment: An International Journal, doi: 10.1080/10807039.2019.1578946.

141. Zabowski D, Henry C. L., Zheng Z., Zhang X. 2001. Mining impacts on trace metal content of water, soil, and stream sediments in the Hei River Basin, China. Water, Air, and Soil Pollution 131: 261-273, 2001.

142. Zhang, C., \& Wang, L. (2001). Multi-element geochemistry of sediments from the Pearl River system, China. Applied Geochemistry, 16(9-10), 1251-1259. https://doi.org/10.1016/S0883-2927(01)00007-5

\section{Figures}

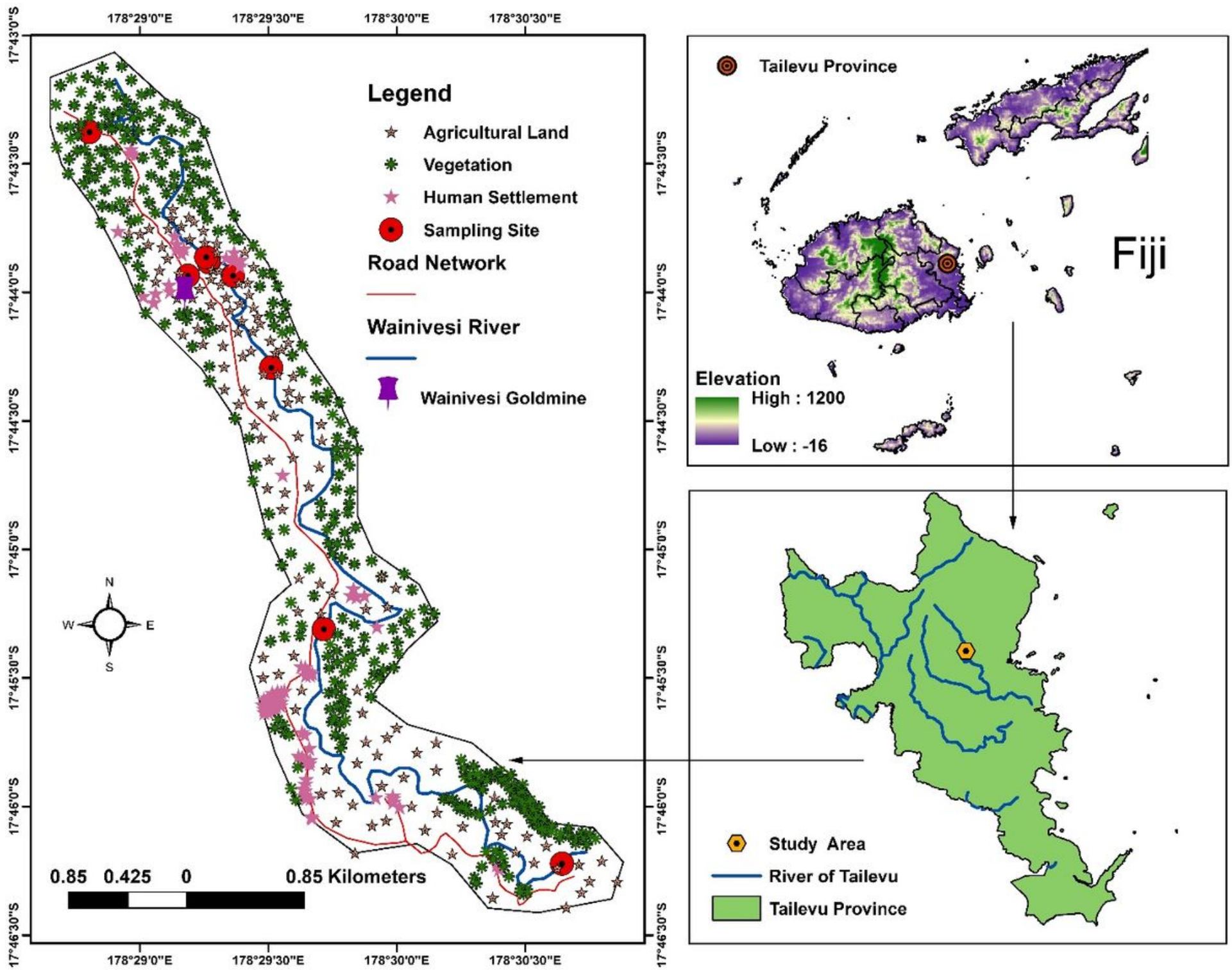

Figure 1

Map showing the Wainivesi River, Fiji and sampling sites 


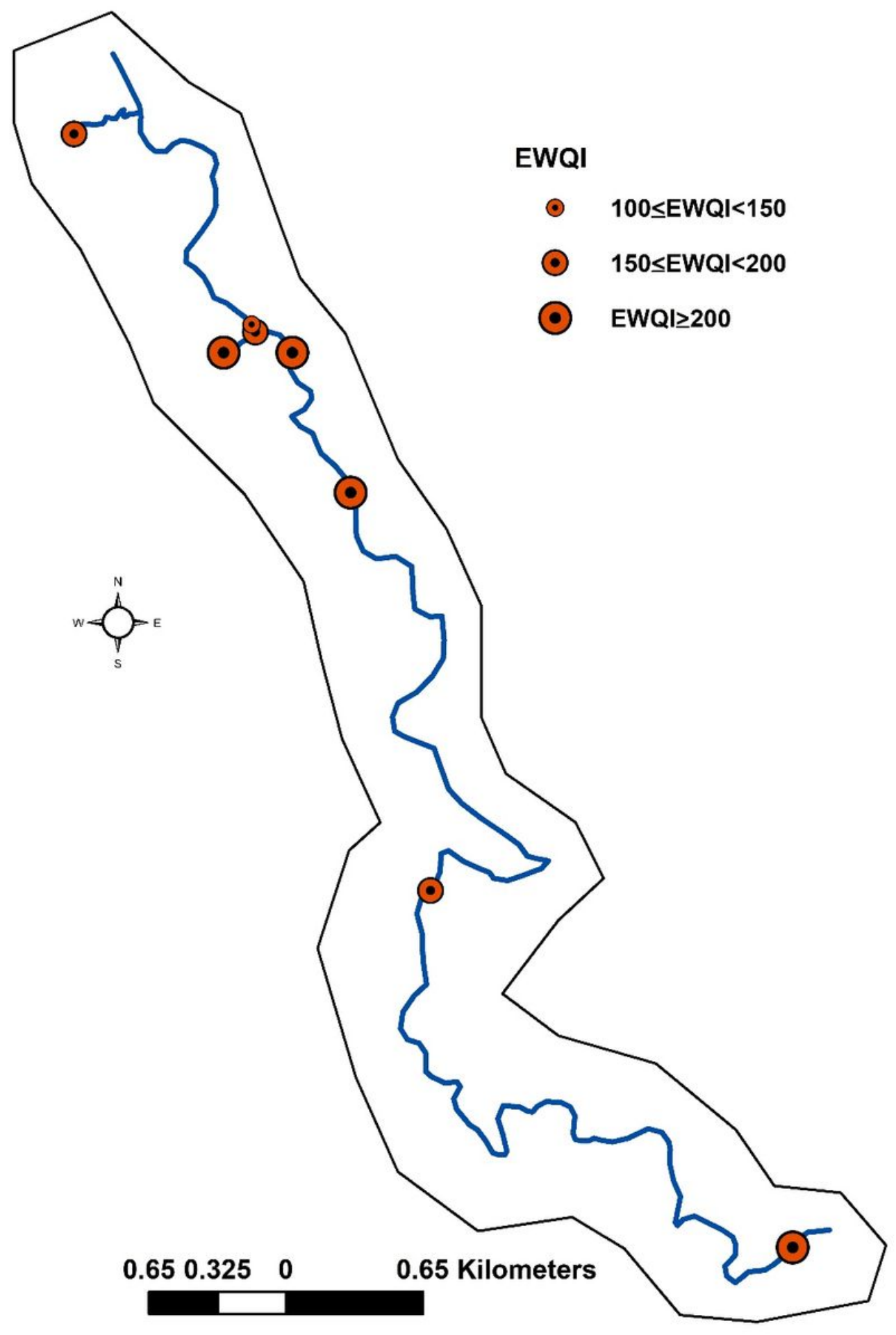

Figure 2

Spatial variation of the entropy water quality index (EWQI) in surface water 

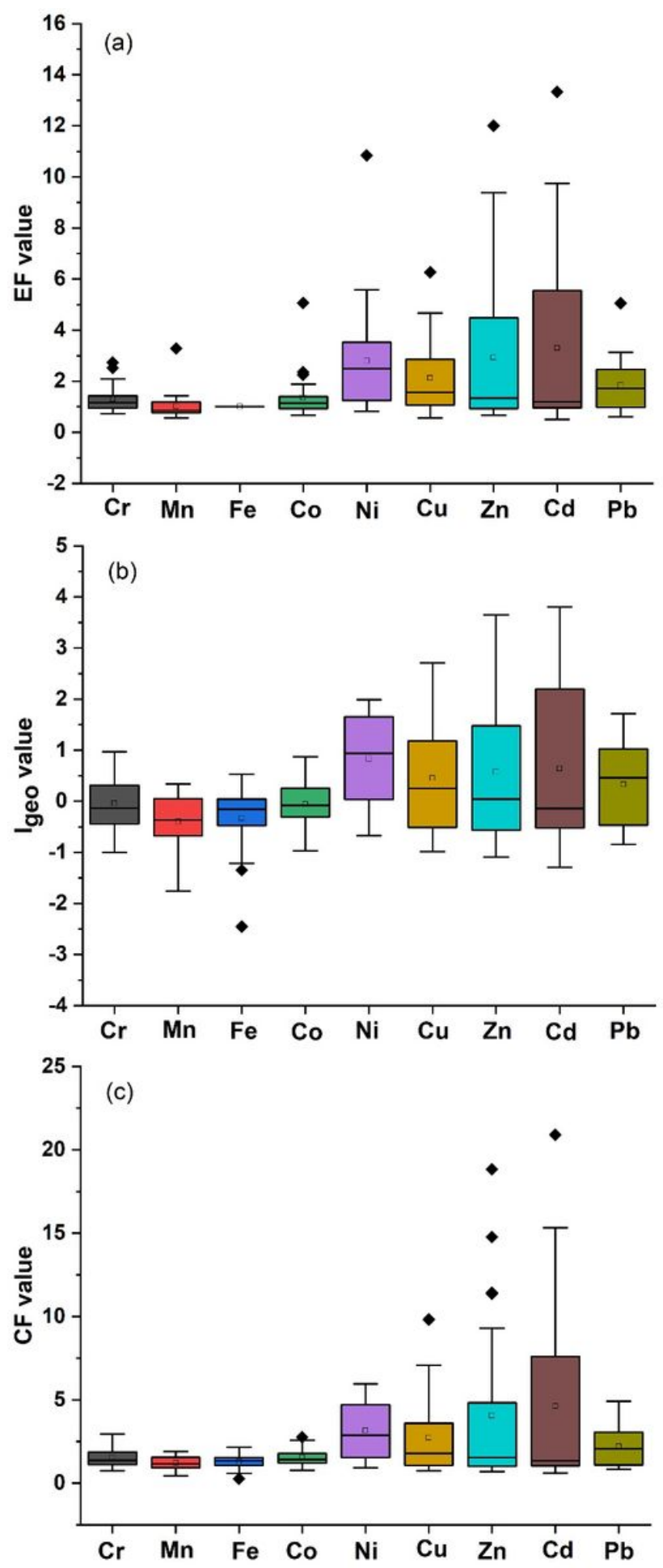

Figure 3

(a) Spatial variation of Enrichment factor (EF); (b) Spatial variation of geo-accumulation (Igeo) index; (c) Spatial ariation of contamination factor (CF) in surface sediment 

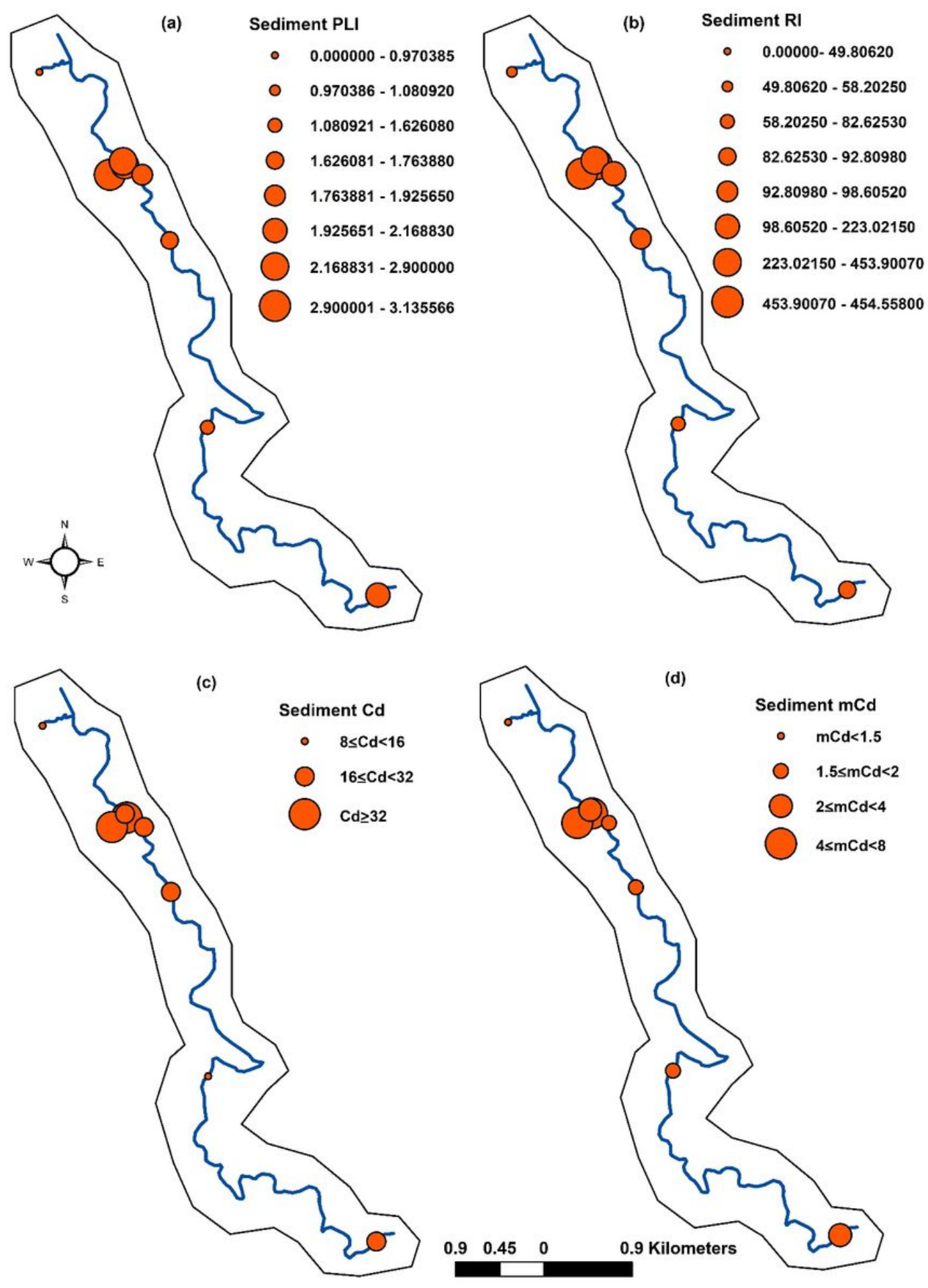

Figure 4

(a) Spatial distribution of pollution load index (PLI); (b) Spatial distribution of Ecological risk index (RI); (c) degree of contamination ( $\mathrm{Cd}$ ) and (d) Modified degree of contamination $(\mathrm{mCd})$ for the surficial sediments of Wainivesi River, Fiji. 
(a) Surface water

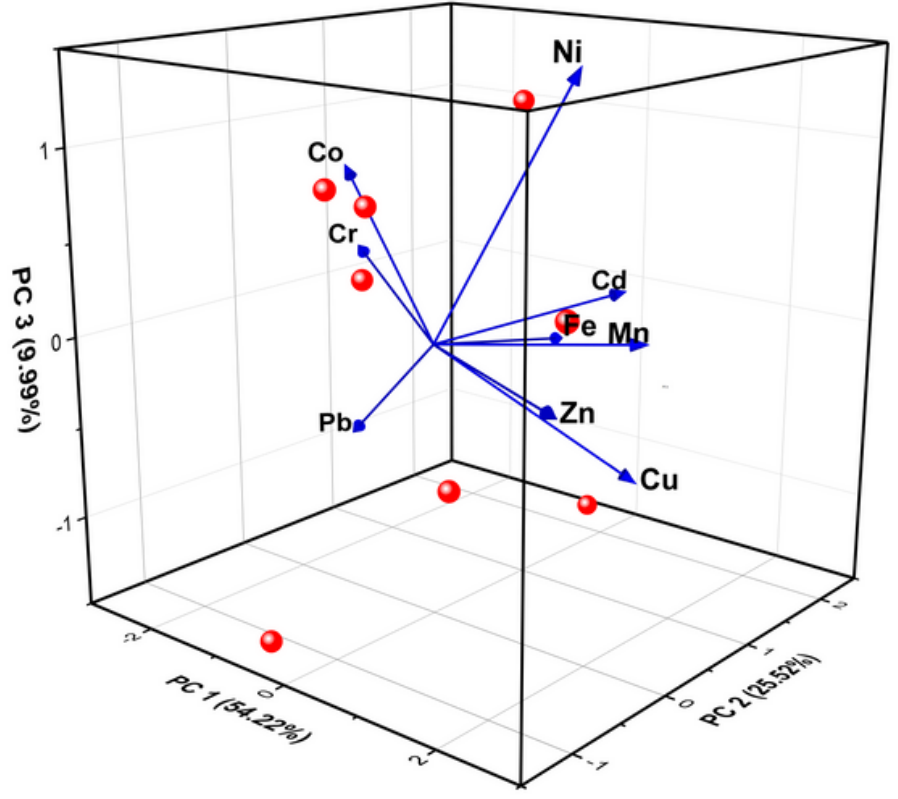

(a) Sediement

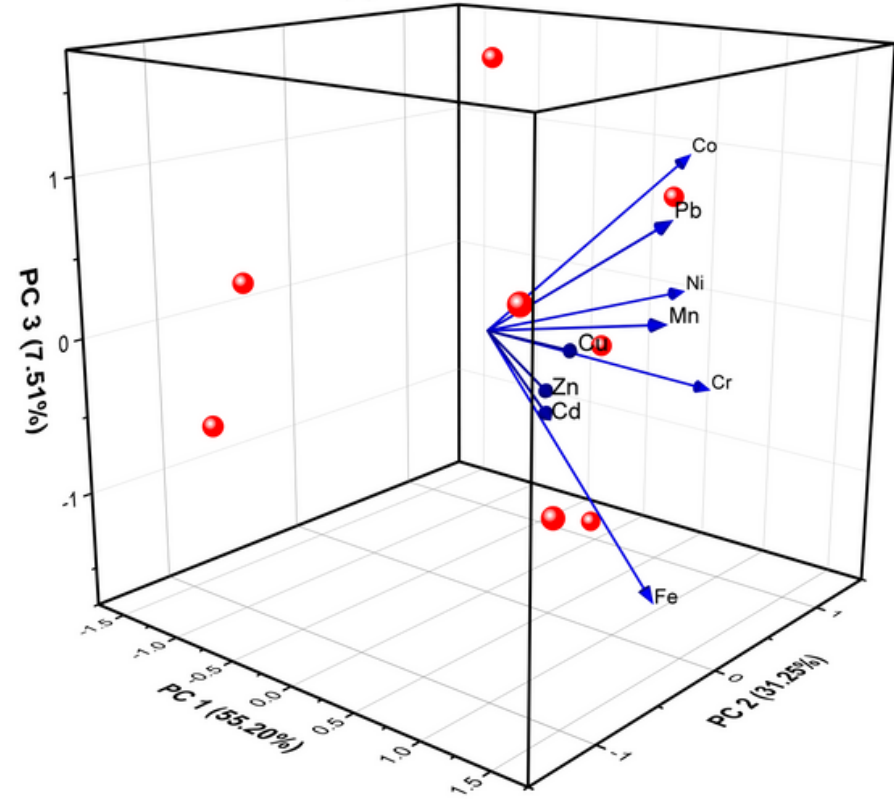

Figure 5

PCA analyses of PTEs concentration in (a) surface water and (b) sediments.

(a) Surface water

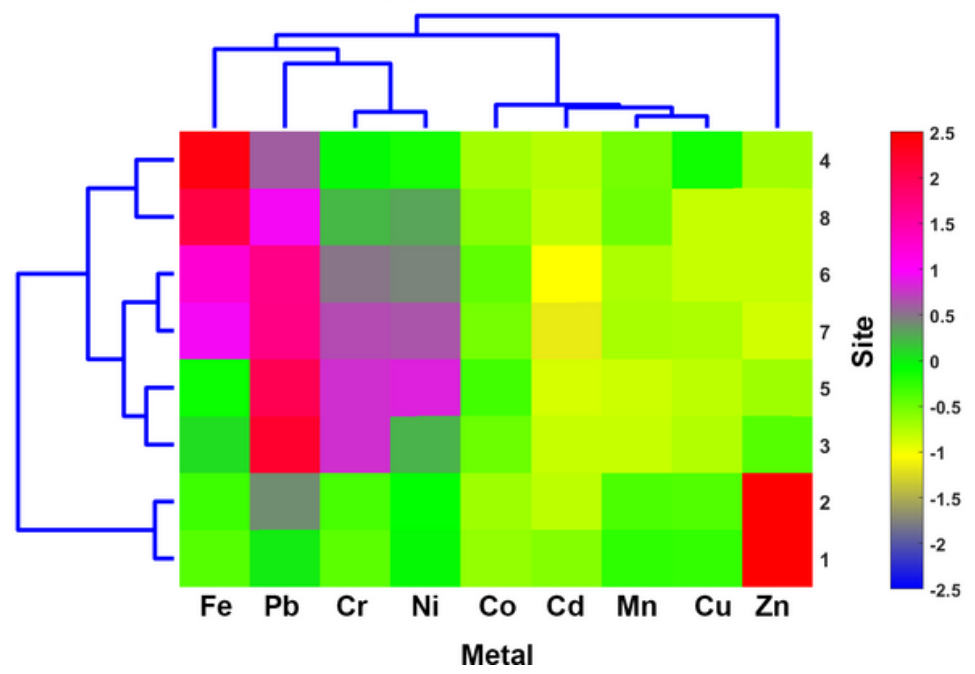

(b) Sediment

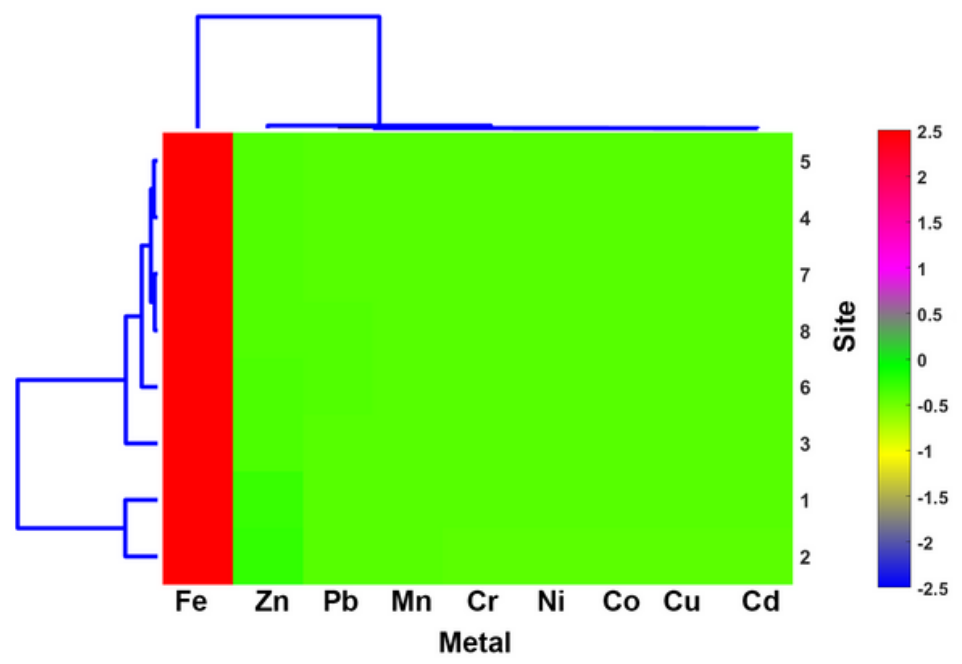

Figure 6

Cluster heat map of concentration of PTEs and sampling sites in (a) surface water and (b) sediment 
(a) Surface water
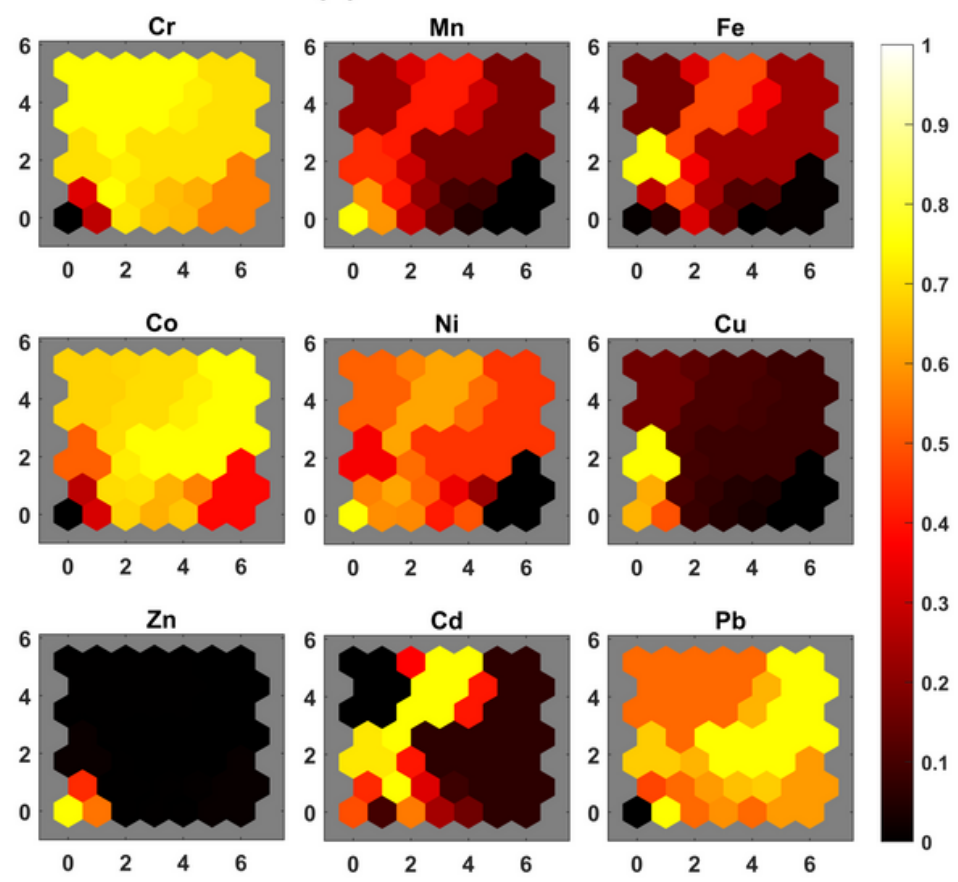

(b) Sediment
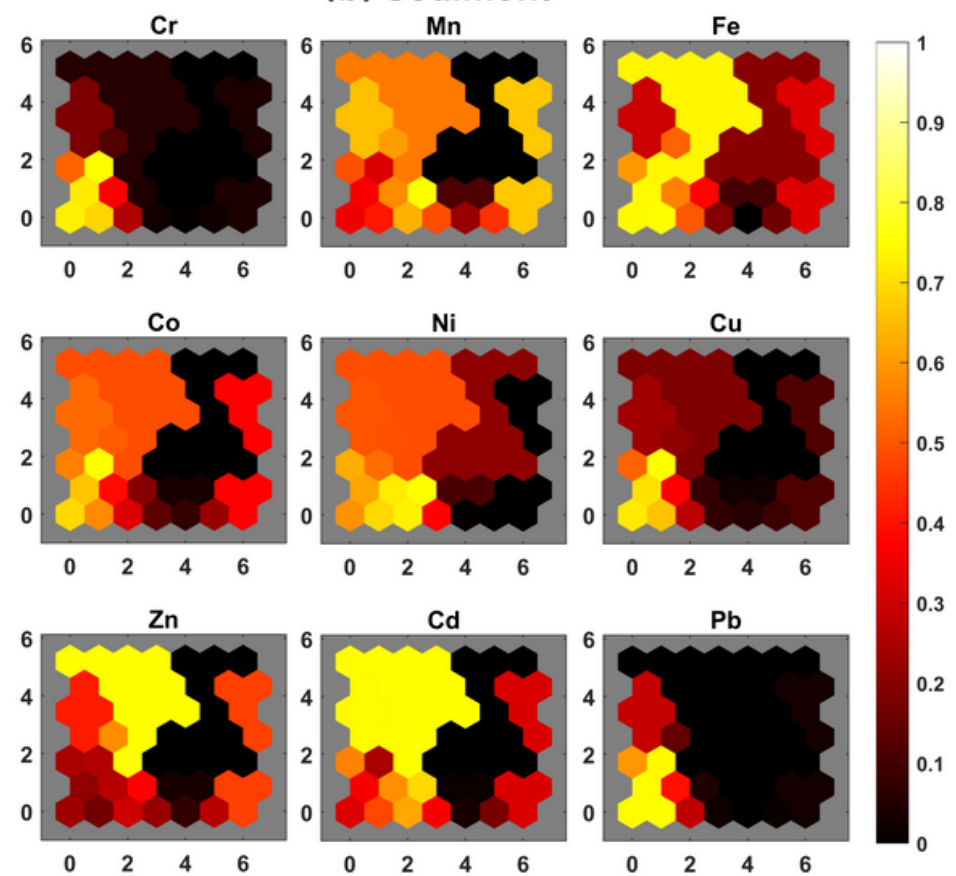

Figure 7

SOM analysis of concentration of toxic metals in (a) surface water and (b) sediment

(a) Surface water

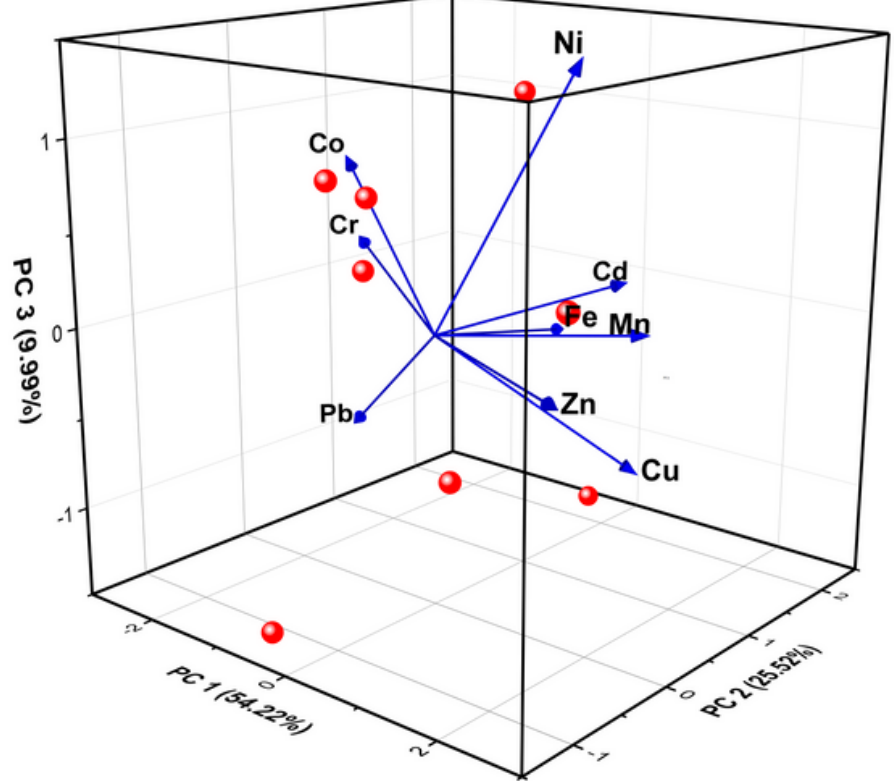

(a) Sediement

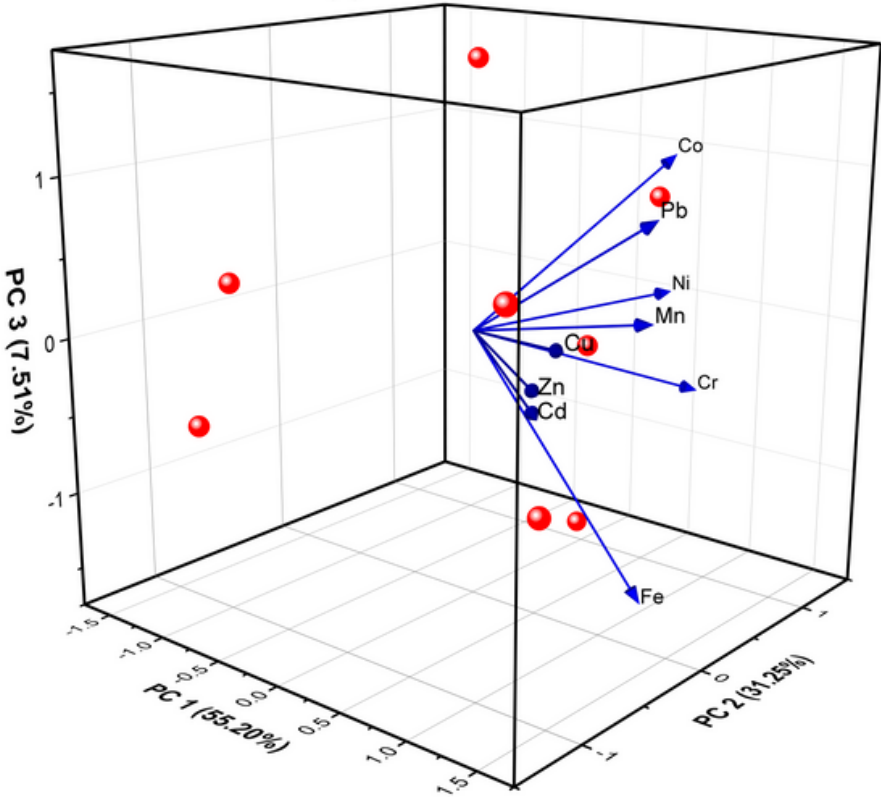

Figure 8

PCA analyses of PTEs concentration in (a) surface water and (b) sediments.

\section{Supplementary Files}

This is a list of supplementary files associated with this preprint. Click to download. 
- Supplementarymaterial29092021.docx 